\title{
THE CONCEPTUAL AND SEMANTIC SHIFT OF "NOBLE" AND ITS SYNONYMS AS A CASE OF SEMIOSIS
} Tatiana Komova, Anastasia Sharapkova ${ }^{1}$

Komova T. \& Sharapkova, A. (2017). The conceptual and semantic shift of "noble" and its synonyms as a case of semiosis. In Lege artis. Language yesterday, today, tomorrow. The journal of University of SS Cyril and Methodius in Trnava. Warsaw: De Gruyter Open, 2017, vol. II (2), December 2017, p. 97-147. DOI: 10.1515/lart-2017-0014 ISSN 2453-8035

\begin{abstract}
The paper explores the interrelation between the socially biased phenomena, affecting the conceptual domain of "knighthood" in the XIII-XV centuries. Nobility and knighthood as interrelated conceptual entities became increasingly complicated, due to cultural semiosis, which brought about drastic conceptual and semantic changes in the adjectives under scrutiny: worthy, noble, gentle. The analysis of corpus and lexicographic material as well as romances of the period demonstrated that conceptual changes became the major triggers for the large-scale semantic changes within the category.
\end{abstract}

Key words: knighthood, semiosis, lexical-semantic shift, metasemiotic shift, socio-cultural factors, Middle and Early-Modern English discourse, noble.

\begin{abstract}
I was given a pointer in the right direction by the question as to what the terms for 'good', as used in different languages, mean from the etymological point of view: then I found that they all led me back to the same conceptual transformation, - that everywhere, 'noble', 'aristocratic' in social terms is the basic concept from which, necessarily, 'good' in the sense of 'spiritually noble', 'aristocratic', of 'spiritually high-minded', 'spiritually privileged' developed: a development that always runs parallel with that other one which ultimately transfers 'common', 'plebeian', 'low' into the concept 'bad'.
\end{abstract}

(F. Nietzsche "On the genealogy of morality)

\section{Introduction}

One of the most gripping issues posed by language has always been the question of how a form gets its meaning and what gives an impetus for its change. Arguing the

\footnotetext{
${ }^{1}$ This paper is dedicated to the memory of Tatiana Andreevna Komova, who passed away earlier to see the results of our work published. I am sincerely grateful for her helpful advice, scientific rigour, patience, and calm good humour. She had a true nobility of heart. 
centrality of the notion of meaning, Jackendoff compared it to the "Holy Grail" for the disciplines comprising the cognitive framework such as linguistics, philosophy, and psychology. In the light of this emphasis he further stresses that "understanding how we mean and how we think is a vital issue for our intuitive sense of ourselves as human beings" (2002: 267). Meaning making is indeed what constitutes both the major problem and the primary inspiration for the linguistic endeavour.

In the early modern period with a structural perspective (Saussure 1959) the research was organized around the notions of the system, the sign, the norm, and the universal. The semiotic nature of language was accepted to serve as the basis for language being primarily a tool of communication. However, with the understanding of a certain misbalance between a model and a real functioning of the language, new approaches emerged. They focused more on a process rather than the system, a semiosis rather than the sign, and diversity rather than the norm. These approaches started to complement item-based approaches with complex network-based approaches (Beckner et al. 2009; Frank \& Gontrier 2010). Starting with the 80 s of the XX century, the prominence of universal cognitive mechanisms and extra-linguistic factors has been acknowledged. The pioneering prior research within the cognitive and functional paradigm focused on distinguishing between meaning and use, core and periphery, text and discourse. Nowadays, it is generally accepted that the linguistic landscape is intrinsically unstable, where dynamism, fuzzy zones, and various misbalances are the rules, but not the exceptions. Thus, integrated approaches are becoming more and more popular as being more apt for subtle trends.

With the latest advances in cognitive research, corpus linguistics, and semiotics the meaning can be studied with the extra-linguistic factors taken together and several methodologies brought together. Cognitive linguistic and semiotic perspective may be combined with the detailed investigation of extra-linguistic factors by means of traditional philological approaches: "Cognitive Linguistics in the new millennium is characterized by a growing attention for the social and cultural aspects of language" 
(Geeraerts 2016: 527). This new perspective may be fruitful for the study of large-scale meaning evolution cases and complicated conceptual domains, such as the domain of knighthood rooted in the culturally and historically dependent representation of nobility.

Thus, the major objective of the present work is to discover the semiotic pathways a developing concept may take to step into a linguistic reality (onomasiological perspective) and major 'bridges' of mutual influence between words, semiotic bindings between cognitive, semantic, and linguistic representations. In this paper, we discuss basic research in the areas of cognitive linguistics, cultural and historical semiotics, and highlight the importance of contextual factors in forming semiotic bonds and thus taking part in meaning development at large.

The aim of our analysis is twofold: 1) examining semantic changes in a group of words (worthy, noble, and gentle) representing a category of nobleness and 2) explaining the semantic change through a conceptual transformation triggered by social changes in how knighthood was positioned in literary and historical context. We proceed from several principles most aptly formulated by Clausner and Croft: "(i) the basic semantic unit is a mental concept; (ii) concepts cannot be understood independent of the domain in which they are embedded" (1999: 1). We explore the semantic category of nobleness within the domain of knighthood being highly complex and inhomogeneous but still a good model to explicate our theoretical conceptions. In the XIII-XV centuries, the category of nobleness was charged with special value and socio-cultural significance, changed its meaning substantially and ended up signalling much more than its semantic meaning alone.

Our analysis is based on corpus methods to study four works of a similar topic yet of the succeeding periods. We support our analysis with the examples from the Corpus of Middle English Prose and Verse, the Anglo-Norman corpus, and a number of dictionaries (Bosworth \& Toller, Middle English Dictionary, Oxford English Dictionary). Further, two representative works on the knightly world for the English- 
speaking community are subjected to a minute analysis: "Merlin or the early history of King Arthur" (1450), which is written by an unknown author, and "Le Morte Dathur" (1485) created by T. Malory. It is possible, however, that some of the semantic changes we observe on the basis of knighthood-oriented texts may have been evident in religious texts and underwent a cultural transfer, as knighthood at large was greatly influenced by religious norms and morals imposed: "In many points chivalry was only a copy of the Christian religion; and as that religion is divine, and admirably adapted to improve and perfect our moral nature, so the same merit cannot in fairness be denied to any of its forms and modifications" (Mills 1825: 357). However, religious texts were beyond the scope of the present paper as we confine our attention to the most exemplary romances of the period in question.

\section{The lexical meaning at the crossroads of cognition and semiosis}

Dealing with a proverbially basic and bewildering notion of meaning and the theoretical aspects of its development, in this section we would propose a model for semantic changes grounded in the following ideas embraced: language as a means of cognition and communication, social nature of language, semiotic nature of language. A meaning is based on relations with the referent, yet these relations are built up on the social and individual levels. The ideas on the theory of meaning within linguistic framework are deeply rooted in the conceptions of anthropocentric (intentional) cognition aimed at creating sign relations between the three cornerstones of meaning construal: the sign, the reference, the sense of a sign. Still, it was outlined as far back as in the XIX century that the latter two are different from the other notion - the associated idea (Frege 1948) that may be highly individual. The thought, that language aims mainly to verbalize certain senses, was prominent and stressed in various linguistic traditions. Dummett proposed: "If a theory of meaning gives as account of the working of the language to which it relates, then, it must embody an explanation of all the concepts expressible in the language" (1993: 4). Akhmanova defined the meaning as "a specific reverberation which serves as the content for an individual piece of linguistic expression" (1979: 8-9). According to Koubriakova, a concept is defined 
as "an operational meaningful unit of memory, mental lexicon, conceptual system, brain language, and the whole picture of the world reflected in the human mind" (1996: 90).

However, Baudouin de Courtenay was the first scholar to stress two indispensable pillars for understanding how language works, though establishing the ground for further controversies as well: "The first cardinal demand of the objective research in language science should be the assumption of undeniable psychological and social aspects of human speech" (Бодуэн де Куртенэ 1963: 17).

\subsection{The psychological aspect of meaning: semantic and conceptual structure}

First and foremost, let us focus on the psychological aspect of meaning and subject the sense of the sign to further scrutiny. What emerged nearly a century later from a plethora of studies into how the meaning development, is the division into semantic and conceptual structures largely accepted within the disciplines making up the cognitive endeavor.

Semantic and conceptual representations were generally acknowledged to be distinct and non-isomorphic modes of thinking and therefore two separate levels of analysis. It must be noted, however, that these questions date back to an earlier and more overarching question: "Do we think in language or not?" Otherwise, it was stated whether our cognitive processes embedding the linguistic processing are totally distinct from each other. Despite the undeniably crucial and sometimes even defining role of language in cognitive processes highlighted by the Russian school of psychology, it has been also proved that language and thought should be regarded simultaneously as "dialectically unified and distinct" (Vygotsky 1934). The foundations laid by Luria and Vygotsky are still being developed, corroborated, and advanced. "According to Vygotsky's cultural-historical approach (1934/1978), cognitive processes ("complex psychological processes" as he calls them) are social in origin, but complex and 
hierarchical in their structure" (cit. Ardila 2016: 5). The defining role is ascribed to language.

The isomorphism question or difference of these structures has been at issue since the first works in the field of cognitive linguistics appeared (Levinson 1997: 13-17). In these works linguistic and cognitive representations were equated: "The terms semantic structure and conceptual structure denote the same level of representation" (Jackendoff 1983: 95). However, due to advances in empirical psychological research, corpus linguistics and new insights in pragmatics two distinct levels were finally singled out. Evans points out that semantic representation is comprised of semantic structure and conceptual structure. The latter "relates to the non-linguistic knowledge representations that words tap into and can draw upon in situated language use" (Evans 2009: 4). It is necessary to show this division, in particular, to answer the questions: how these structures, being distinct and by no means subordinate to each other, interrelate and ensure successful communication where the individual conceptualizations and the socially shared ideas meet (Levinson 1997).

\subsection{Philosophical, cultural, and social perspectives}

To circumvent this difficulty, several attempts are undertaken to resort to philosophy. The Husserl's phenomenology seemed to overcome the paradox of individual psychological reality and the social nature of communication (Zlatev 2016). Zlatev stresses: "Meaning is not properly speaking 'in' the mind, but consists in the relationship between intentional act and intentional object" (2016: 562). Thus, the intersubjectivity of language meaning is proved. The Popper's notion of "the third world" proved to be useful in Geeraerts's argumentation: "Language, in Popper's view, firmly belongs to the third world, as a symbolic system for representing knowledge and building up argumentation" (2016: 529).

What follows from this is a more complicated nature of a sign. Finally, we get not two or three parts in the sign relation, but four parts: the object, the conceptual 
representation, the semantic representation, and the linguistic form. However, in order to incorporate a semiotic perspective to cognitive framework we should not only differentiate the semantic and conceptual representations, but also understand that for the view of language as complex and dynamic, the notion of a system would be oversimplistic. It was suggested by Akhmanova and further developed by Nazarova, that "a sophisticated linguist will no longer state that language is a sign system par excellence" (Назарова 1996: 20), but will seek to apply a semiotic framework to the analysis of complicated and dynamic processes going on in the language and bound to human consciousness as well as society and culture. Consequently, at least for heuristic purposes we should assume that a linguistic sign functions not in a universal system irrespective of language or culture, but semiotic relations arise in various systems within a language, binding them to other levels. Thus, a linguistic sign may take part in multidimensional semiotic relations reflecting the conceptual change and giving credibility to the linguistic one.

The dichotomy of meaning and use is the fundamental dynamism of meaning triggered by social nature intrinsic to linguistic communication rooted in the inner self of participants. On the basis of all these theoretical assumptions any changes of meaning invariably include a socio-cultural facet both in a narrow and a broad sense. The narrow sense of semantic change occurs, "when speakers decide to accept an innovation because it is convincing to any extent ... based on the innovation's good cognitive performance" (Blank 1999: 62); the broader perspective is, when culturally and socially evolved language systems or their constituent parts develop according to a more widespread variation and change, and promoted by "dynamic mental categories" (Winters 2010: 17).

A growing pile of linguistic and other fields' evidence indicates that large-scale semantic changes should be examined from a broader perspective as the idea of "social semiotics" (Halliday 1978) and "meaning in society" as "the causal interplay between mental and non-mental factors" for "not everything can be captured in terms of mental 
facts" (Harder 2010: 7) or joint meaning-making (Goodwin 2000; Tylen et al. 2013). Since "language change is a consequence of inherent characteristics of man's mind and human social interaction" (Blank 1999: 63) it is natural that any internal and newly evolving balance between the signifie and signifiant in the most general sense entirely depends on the external context in its various forms: the context of a speaker, context of culture, and context of time. The latter paves the way to historical semiotics as a research domain introduced by Uspensky: "the perception of time as a problem of semiosis" (Успенский 1996: 10) when applied to the study of linguistic meaning in a historical context. The major focus is not on the fact itself but on its perception and evaluation, that is in other words, how the semiotic bindings and codes emerge. It must be noted that, "it is the system of conceptions within the society being the addressee of historical communication determines the mechanisms of semiotic binding" (Успенский 1996: 14).

Language as such and hence its semantic system tends to be enactive and dynamic for meaning innovation and adoption processes are in constant turn-taking over centuries; the actual language use continuously reorganizes the shared linguistic knowledge (MacWhinney \& O'Gardy 2015). In the last three decades, models proposed by cognitive linguistics (e.g., radial networks, conceptual metaphors, idealized cognitive models, blends, etc.) and application of corpus 'quantifying meaning' methodology (Biber et al. 1998; Glynn \& Robinson 2014; Zabotkina 2015) have been particularly influential and productive providing an operational answer on how the meaning is changing. It has also become apparent that meaning study should be carried out on both synchronic and diachronic levels ${ }^{1}$ when a semasiological as well as an onomasiological perspective is taken into account. The latter looks more closely at concepts, their architecture "in a group of conceptually related words..." (Geeraerts et al. 1999: 37). The increased emphasis is laid "on the study of various forms of meaning, not as objects or structures, but as processes on various time scales, from those of evolution and development to those of "the human level" of social interaction, to the micro-level of "time consciousness" in retention and pretension process" (Zlatev et al. 2016). 
Therefore, the extra linguistic drivers of changes become specially brought to the limelight and foregrounded in linguistic analysis thus leading to the socio-cultural turn in semiotics accompanied and enriched by the semiotic turn in cognitive linguistics ${ }^{2}$. The fundamental pillars, outlined by Baudouin de Courtenay, seem to be relevant again, yet enriched by numerous studies and extended to new domains of linguistics.

Dynamism is at the core of meaning making and the metaphor of the Holy Grail we started from is true not only in terms of infinite search for it, but also in terms it inevitably vanishes in case one grips it. Very much in line with these ideas Eco underlined: "The concept of sign must be disentangled from its trivial identification with the idea of coded equivalence and identity; the semiosic process of interpretation is present at the very core of the concept of sign" (1986:1). This claim perfectly fits into understanding of basic cognitive processes reflected in the language conceptualization and categorization.

These ideas could be schematically summarized in Fig. 1. Here we put forward a model uniting the insights from semiotics as well as cognitive linguistics, relying also on extensive philological and cultural-historical background. The contextual forces are acting on the representations all at the same moment, so unless any is prioritized by any reasons it is difficult to disentangle them from each other and the general picture gives an impression of a perfectly ordered system. 


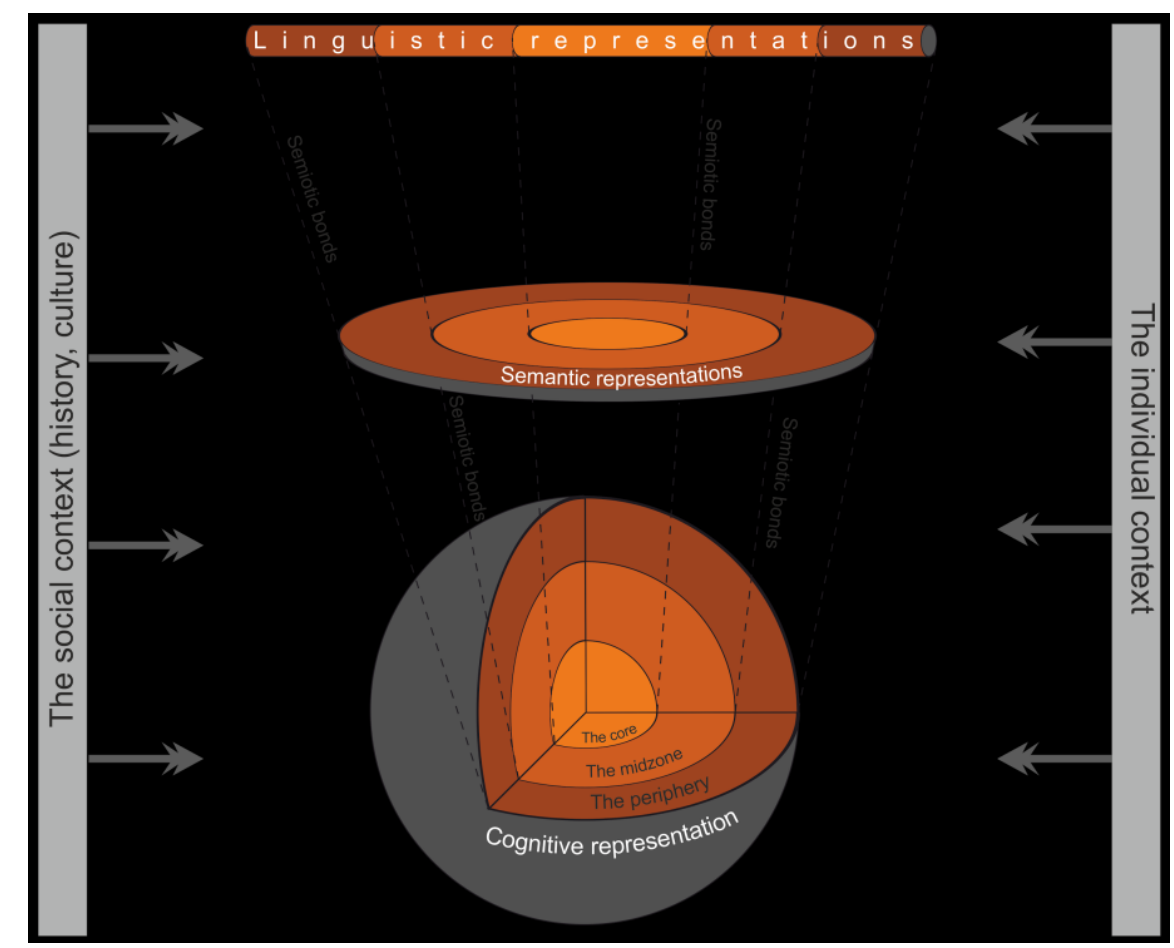

Figure 1. The schematic representation of the representations developing with the correlations marked

In this paper, we try to shed more light on how the semiosis is taking place at the crossroads of culture, society, and literature on one particular case - the development of the semantic category of nobleness based on analyzing a set of words, verbalizing this category throughout the centuries. We embrace the historical domain of linguistic experience to show the process of conceptual development and semiotic bindings emerging in dynamics. Since a closer scrutiny of the nature of linguistic processes provides the best argument for theoretical models, we focus on those words that are especially charged in social and cultural terms. The conceptual domain of knighthood is studied on the basis of two representative works, manifesting the chivalric code. Studying the literary texts is necessary not only because we can't get access to largescale linguistic changes in the past otherwise, but also since these changes are especially visible in literary writings, where speakers are particularly conscious in their choice of words, "a work of literature distills creative imagination into excellence of linguistic expression" (Quirk \& Stein, 1993). To put it in a nutshell, the romances apart from pure artistic aims endeavoured to create a new socially-biased semiotic paradigm where the concept of nobility was understood as a special socio-cultural sign. Hereafter, from structural semiotics we proceed to a more discourse-oriented semiotics 
(aiming at "typological investigation of narrative" (Nazarova 1996: 25) and cognitive semiotics (understanding how we comprehend and mean (Brandt 2004). Therefore, the category of nobleness helps us fulfill a sociopragmatic requirement and elucidate how communication takes place in language, by language and through language (Успенский 1996). The meaning of a word being a sign of the basic level in the course of time and in certain discourse settings may shift to a level of a metasign (Назарова 1994; Akhmanova 1979; Hjelmslev 1969; Nasarova 1996). Within this framework, it is not the semiotic system, but the ongoing semiosis, binding various semantic and cognitive representations and linguistic signs that attain greater importance and attention. The word within distinct socio-historical settings can shift to a level of metameta sign.

\section{The noble case: the origins of the category and primary semantic shifts}

The lexical category of adjectives and nouns appeared in the flood of borrowings from the language of the new elite. Yet, gradually they started to fulfill also the axiological function in a newly formed feudal system and represent the knightly worldview of the Middle Ages. Thus, the adjective noble appeared in the English language of the XIII century not solely as one from the stream, but more as a historical and cultural sign, thus verbalizing transition from the previous semiotic status to a new one inspired by a novel social system.

\subsection{Placing noble within the socio-historical and linguistic context}

Having the original meaning of high social rank, noble replaced several Old English words of Germanic origin. One of them was ceðel(e) (ceðel-boren), tightly bound with a notion of a piece of land and used in a number of compounds (Aeðelstan, ceðelhceleð). Interestingly enough, ceðel was mostly translated as nobilis into Latin: Sum aeðelboren man - homo quidam nobilis (B\&T). Thus, we may state, that a new form noble replaced the older one ceðel(e). At the first level of semiotic interpretation the form and its content are distinct and clear in a linguistic sign. This process echoes the ideas by Benveniste: any element of language may be a 'sign' and 'word' according to the 
semiotic or structural semiotic or semantic perspective (cit. by Baum 1977: 12). We may also add that it may be a concept within the conceptual system. Still, if we look closely at the new word, we would notice that despite significant semantic similarity, it signified another social system to be brought to the foreground of the historical stage - feudalism as a system of new socially and culturally biased signs. Because it substituted the Old English word with largely the same meaning we can reasonably project and justify its historical semiotic function: "He (William the Conqueror) revolutionized the social, political, and military structures of England replacing the English athelings with French nobles" (Vennemann 2012: 961). The ultimate bond with the previous period was broken and a new semiotic bond emerged. Paradoxically, it turned out to be smother for the language rather than for the social life given the early Romanization and progressive Christianization thus establishing the ground for the concepts of nobility and the word itself to be tranfered:

"Underlying the Germanic actualities lay the inheritance of Roman constructions of a civil aristocracy, based on birth and civic/imperial service. Roman law principally distinguished between free and unfree and between citizen and non-citizen, but the Roman world distinguished also between 'patricians' and 'plebeians', and the distinction between 'nobiles' and 'ignobiles' established itself in the realities of legal, social, and political life" (Duggan 2000:2).

Noble, as a new word, also ousted another recurrent word in Old English - freo, which was used to describe noble, or better say, free people in opposition to slaves or serfs. The adjective free also adjusted its meaning and in some contexts of Middle English romances it is equal to noble: Seigramor, gentill squyer, fre and debonai (Seigramor, a gentle squire, free and courteous) (Merlin: 262). Still the adjective noble started to be more and more pervasive as the study based on Anglo-Scottish ballads of the XIII century demonstrated: the old word ceðel is no longer found, but free (freo) is used to describe people of high rank equal to noble at that time just appearing in similar contexts (Бердникова 2011: 113). During merely one century from the XIV to XV the meaning of the word noble changed drastically from "superior birth" related to gentry to "having high moral qualities" thus pointing at the changed semiotic bonds between a linguistic form and a conceptual representation. Lewis explains this lexical pathway 
through tension, appearing when two dominant senses - social and ethical - came into contradiction in reality:

"The mind cannot long consider those manners and that character without being forced on the reflection that they are sometimes lacking in those who are noble by status and sometimes present in those who are not. Thus, from the very first the social-ethical meaning merely by existing is bound to separate itself from the status-meaning" (Lewis 1960: 22).

This might be the case later and due to another literary tradition ('ungentle gentles' as opposed to 'gentillesse cometh fro God allone'), however this does not explain the very first stage of meaning shift: how these two meanings came tied together and the ethical one became exceptionally prominent.

\subsection{Noble as a marker of the social identity of knighthood}

Given that any language is deeply grounded in speech communities and meaning evolves in its interaction with the world, we hypothesized that this transformation was shaped initially by changes in the conceptual representation of knighthood in its turn determined by changes in society. Since we are dealing with the concept of nobility, the changes have to be deeply rooted in the social institution of knighthood as indissolubly connected with a shared historical-cultural phenomenon. Its most powerful image - a noble knight in 'shining armour' was made up of a set of stereotyped features more or less successfully (in artistic terms) portrayed by individual literary characters. This idealised image laid a common conceptual ground for evaluating knights and their behavior in numerous romances. The most recurrent collocation for the adjective noble both in Middle English and Anglo-Norman Corpora is knight and chevalier respectively.

The notion of nobleness and thus the knight's 'goodness' was directly influenced by personal, group, and class self-identification: an ignoble knight was deprived of his knighthood and certainly nobility. The conceptual representation of nobility evolved later on the basis of the borrowed adjective noble penetrating the language. Noble expresses neither a quality by itself nor is it characterized by a rigid semantic structure; 
it is first and foremost a property of a knight, thus semantically feeble and frail without its 'natural object' of nomination and, consequently, easy to adjust its content to new social/cultural claims. This entailment between the object and its quality and a new object derived from an abstracted quality is the basic and the most universal one (see Комова 1990; Кубрякова 1978; Потебня 1999).

Summarizing, the semantic changes should be studied with regard to changes in conceptual structure and in the interactional perspective, i.e. how a particular sign of a language is used to convey meaning within a particular context.

\subsection{The complicated nature of nobility: three types of knighthood}

However, knighthood as a newly formed aristocracy was not a monolithic entity with a unified system of values. The concept, underlying semantic changes, was far from being holistic that is justified by the very nature of a concept firstly resulting from processes of conceptualization and categorization open to continuous innovation and revision. Quite the contrary, it underwent at least three important conceptual shifts resulting in a more complex picture on the onomasiological level (the level of content for developing a conceptual category). Moreover, unlike many un-reflected concepts the knighthood identity, resting on nobleness, was highly conscious and in some way deliberately constructed. The reasons for this noteworthy change should be looked at the conceptual level and how it was influenced by the contextual forces (Fig. 1).

Kennedy makes it clear that three major types of kinghood emerging in social reality further multiplied in literature: the noble warriors - courageous and skillful in battle and invariably loyal to the lord, the ideal knights, the best qualities of whom are piety, chastity, humility and who are characterized as true Christians, and at last - the knightcourtiers - those at ruler's service whose proper "competence in the courtly pastimes" is necessary (Kennedy 1992: 14-16). This typological set outlining a feudal hierarchy of Europe was a response to the insistent claims of society and a new aristocracy in statu nascendi in the Middle Ages. Moreover, these types (no matter that they emerged 
one after another) started to merge at the period of Malory's "Le Morte Darthur". Interestingly enough, the transformations in social life influenced the 'knightly discourse'; linguistic representations had similarly given rise to changes in both: word semantics and the development of social behaviour of knights when medieval romance seemed "unexpectedly like history" (Field 1982: 39). Hereafter, the language describing the knightly values had to adjust to these changes either by adopting new words or by altering the meaning of the already existing ones relying on the intrinsic lack of rigid semantic structure. And the words themselves moved towards new challenges imposed by the society and culture, thus shaping the category in question. The domain of knightly qualities and characteristics expanded and became more and more elaborated in the course of time. New social needs led to profiling and foregrounding one of the elements in 'knightly discourse', while keeping the others at the background.

Moreover, stepping from the abode of pure semiotics where we can find a sign, i.e. one to one correspondence between the form and the content in the world, the sign is becoming a cultural marker with a purport, possible to be transmitted firstly to metasemiotic and then higher - to meta-metasemiotic levels. Therefore, a sign taken as a whole may function as a form for a more complicated content on another level literature or culture (Ахманова 1979; Назарова 1994). Yet, it is not an easy matter to formulate such a mutual dependence for all the vocabulary of the language. However, what emerges from the above description is that this idea holds true for the lexical categories of profound emotional value and its metasemiotic potential, thus being "cultural" entities according to Sperber who made clear that "emotionally marked concepts can serve as an onomasiological "center of attraction" for other words to verbalize the "attractive" concepts and, vice versa, serve as a cognitive basis, as a semasiological "center of expansion" for verbalizing other concepts" (cit. Blank 1997: $67)$. 
The conceptual representation, as it has already been argued above, is connected with the semantic and linguistic representations through inner semiotic bindings. They emerge, strengthen, and vanish throughout the time. Albeit the conceptual representations shape the linguistic ones to a large extent, the opposite seems to be also true. Thereby, the onomasiological or top-to bottom perspective is to be complemented by a bottom-up semasiological one (more on onomasiology and semasiology in semantics see Geeraerts 2010).

In the course of featuring "knighthood" the adjective noble is the most apparent and abstract representative of the domain under scrutiny. Noble presupposes a conceptual link to good, all other members of the category are conceptualized through noble set of words: noble, worthy, gentle, courteous, valiant, etc. In spite of vagueness of good or even due to it the adjective good is nearly two or three times more frequent in both novels than worthy or noble (305 to 146 in "Merlin" and 1048 to 459 in "Le Morte Darthur"). They stay within its 'umbrella' conceptual dominant of noble - the major focus of our attention.

\section{The development of the lexical category in Middle English}

In this section we mainly focus on lexicographic and corpus material to reveal the major steps the semantics of words (noble, gentle, worthy) developed by. Since we work with the category of nobleness we immediately turn to pay attention to the words within their surrounding. We also point to some possible relations arising within the lexical system of the time. In the final part of the section we provide a quantitative analysis of the words used in four works united by the same topic.

\subsection{The development of worthy}

One of the words of the category is worthy, for it is the only word of Germanic origin within the examined lexical category. The old English weorp (wurð) meant "equal in value to, having value mainly speaking about material things" and it referred mainly to objects with regard to their price "of the value of a specified amount" (The Concise 
Oxford Dictionary 1993: 1721). The example: 1303 R. Brunne Handl. Synne 6323 Hys vessel was ten mark wurpy [v.r. wrpy] (OED). It was scarcely functioning in the contexts describing human behaviour. In the Oxford English Dictionary: 2. a.A.I.2.a Of persons: Distinguished by good qualities; entitled to honour or respect on this account; estimable (OED). As far as the field of war-fare is concerned, it formed a nominative compound wigena weorðmynd "the fame of warriors". The adjective was derived - weordful corresponding to "having worth, worthy, honourable, glorious, excellent, held in honour, honoured, esteemed" (B\&T). Etymological dictionaries identify the form worthy with $y$ or $i$ at the end as a neologism of the XIII century used predominantly in one sense - "having merit". K. Horn (Harl.) 1222 For per buep myne knyhte worbi men \& lyhte, armed vnder clope (For there are my knights, worthy men, alight (not on horses)/quick, armed under their clothes). 1338 R. Brunne Chron. (1810) 162 Of his men most worpi, at pam conseile gan [he] take (He went to ask advice from those his men, who was the most worthy) (OED). We don't observe any reference to 'gentle birth' or aristocratic status in the semantic structure of this word yet. It could have resulted from a transformation of social framework with an increasing interest in Christian virtue and the meaning of "price" gradually fading away.

The vacant place of a word denoting price in the conceptual sphere was temporarily taken by valour, which was borrowed at the same period from Old French dating back to Latin valorem "†value, worth" (The Concise Oxford Dictionary 1993: 1649). Further on, with knighthood on the historical social scene and abundant French romances its meaning of "valor, moral worth, merit, courage, virtue" became the first according to the Middle English Dictionary, while "the monetary sum representing the value of something, price" - the second one. Moreover, influenced by another lexeme of the same root-value and courtly culture featured in romances of the XIV century it further split into "courage" being the second, and knightly virtues in general are brought to the limelight: "worthiness in terms of the chivalric virtues, nobility of character or breeding; also, spiritual worth [quot. 1475]; also, courtliness, refinement [quot. a1500 
(?a1400)]" (MED). Thus, the process of change in the semantic core of the linguistic sign is manifested for the users of language.

\subsection{The development of gentle}

Another lexical item, which is of particular interest is gentle (gentile), not only because it follows the general pattern of conceptualizing new cultural phenomena, but it is also borrowed in the same period - at the very beginning of the XIII century. The dictionary, pointing to the meaning of "well-born, of noble rank or family" (The Concise Oxford Dictionary 1993: 640) makes clear that at the same time "character or manners befitting one of gentle birth" (MED) is essential. The second meaning points directly to knighthood as the driving force behind all these semantic changes: "(a) Having the character or manners prescribed by the ideals of chivalry or Christianity; noble, kind, gracious, etc.; (b) courteous, polite, well-bred, charming; graceful, beautiful, handsome" (MED). Turning back to the classification of knightly types by Kennedy, we should note that these changes keep up with the new types: from more archaic and war-fare focused to more abstract and merit-oriented. Yet, in the majority of cases the types are more or less distinct and identifiable.

The examples from Middle English Corpus of Prose and Verse serve as keynotes with regard to the timeline: 1) Sir James of Auenu, he had pe first eschele (a battalion) Gentille of norture, \& noble of linage Chron.Pt.2 (Petyt 511) p.188). Here the basic meaning of gentle birth is profiled and stressed, for two lexemes are working in duplets; 2) Redeth Senek and redeth eek Boece! Ther shul ye seen expres. That he is gentil that dooth gentil dedis (The one is gentle who performs gentle deeds) (c1395) Chaucer CT.WB. (Manly-Rickert) D.1170). In the second example we observe the elaboration of the idea of being gentle by birth accompanied by some gentle deeds as well as a high-minded heart and thoughts; 3) Lordis schal be noble \& gentil of herte, of fleisch, \& of bouzt (a1398) (Lords shall be noble and gentle of heart, flesh and thought) Trev. Barth.(Add 27944) 73b/b). The analysis has shown that the combination of two adjectives: noble and gentle in the same context serves the purpose of strengthening 
(reinforcement) of all the shades of their meaning.; 4) De gantyl knyzt... seyde, 'Gramarcy, my swete wyst!' (creature) (a1500 (?a1400) Chestre Launfal (Clg A.2) 334). And in this context a set phrase - gentle knight - points to some peculiarities of a knight-courtier most probably talking to a dame. He possesses manners taught and aspired to and a distinct speech portrait of a gallant lover (MED).

These examples lead us to assuming that the words noble, worthy, valiant and gentle, existed in the state of flux with numerous fuzzy zones intersecting, because they represented the most essential cultural markers being formed and transformed. The unity of signifier and signifiant is therefore constantly violated and successfully restored in the context due to the ongoing cognitive processes in an individual mind influenced by intersubjective communication. The links of correspondences between the form and the content in the words within the category are becoming more complicated and diverging.

The contradiction between the types contesting in the immediate context of occurrence is exemplified by an early source corresponding either to 1300 or 1325 , where gentle is collocated with hard, highlighting true knight's behavior in battles, cf.: So large he [Arthur] was \& so hende \& al so debonere, So hardi \& so gentil \& of so vair manere (He was so large (great), so refined and gracious, so hard and so gentle and of so true sort) (MED).

\subsection{The development of the category}

To put it in a more general way, all the members of the conceptual domain could be classified into those evolving semantics from concrete, less general to more general and represented in terms of a radial category with one member at the core being prototypical to the others at the periphery. According to Lakoff, "a radial structure is the one where there is the central case and conventionalized variations on it which cannot be predicted by general rules" (1987: 84). In attempt to establish a typology of semantic changes in the light of cognitive linguistics, Blank specially noted that 
"fixation on the prototype triggers the semantic change" (1999: 76). And this idea offers a high explanatory potential in the case of noble (forming the base of a networking process of the word meaning and its synonyms within the category). The first member that started to move towards the central position, which in its turn caused the expansion of its semantics was worthy. In the XIII century it began to refer to abstract qualities of a good warrior and a person of some merit. All the others including noble exhibited this tendency further on- in the XIV-XV century. Taking into account three most representative works from the end of the XIV century to the end of the XV century we calculated how many times the words under scrutiny were used. We start with "Canterbury tales" by Geoffrey Chaucer, proceed with three more works including "Merlin", "Stanzaic Morte Arthur", and "Le Morte Darthur" in a linear order. However, we subject two romances to scrutiny - "Merlin or the early history of King Arthur" by the anonymous author and "Le Morte Darthur" by T. Malory. Since it is nowadays largely acknowledged by the Arthurian criticism that Malory was to some extent influenced by the "Stanzaic Morte Arthur" and the interpretation of the main character, we also looked into the number of words in the text (Kennedy 1994). In Table 1 we represent how all the lexemes under investigation change salience within the lexical category (See table 1).

Table1. Frequency of occurrence of the words representing the category in XIV-XV centuries

\begin{tabular}{|l|l|l|l|l|}
\hline \multicolumn{1}{|c|}{ Title } & $\begin{array}{c}\text { The number } \\
\text { of words }\end{array}$ & \multicolumn{1}{|c|}{ Worthy } & \multicolumn{1}{|c|}{ noble } & gentle \\
\hline Canterbury tales (1380) & 188840 & $90 / 0,048$ & $75 / 0,040$ & $69 / 0,037$ \\
\hline Merlin (1450) & 284824 & $146 / 0,051$ & $138 / 0,048$ & $47 / 0,016$ \\
\hline $\begin{array}{l}\text { Stanzaic Morte Arthur } \\
(\mathbf{1 4 6 0} / 70)\end{array}$ & 26252 & $15 / 0,057$ & $20 / 0,076$ & $3 / 0,012$ \\
\hline Le Morte Darthur (1485) & 382874 & $55 / 0,014$ & $459 / 0,12$ & $56 / 0,015$ \\
\hline
\end{tabular}

As these texts are different in quantity of words within the text, so we attenuate this problem by providing percentage as well. The most prominent word used by Chaucer in Canterbury tales was worthy, then the words clearly competed in the prose romance Merlin, and finally, noble significantly exceeds worthy in Malory's work becoming the 
most salient and representing a prime concept for the category. There is a possible misconception to be discarded here: "Frequency of occurrence is not the only factor determining prototypicality, but next to conceptual coherence, it is certainly an important one" (Geeraerts 2010: 75). It goes without saying that context-based study reveals many other nuances of the word in use and more importantly - a balance between the senses of words. The words are not in this case part of the linguistic semiotic system, but are working in a context, their content plane is contaminated by the actual use through the action of contextual forces. Figure 2 provides indirect evidence in favour of the correlation between the prototypicality and salience for the words forming the category.
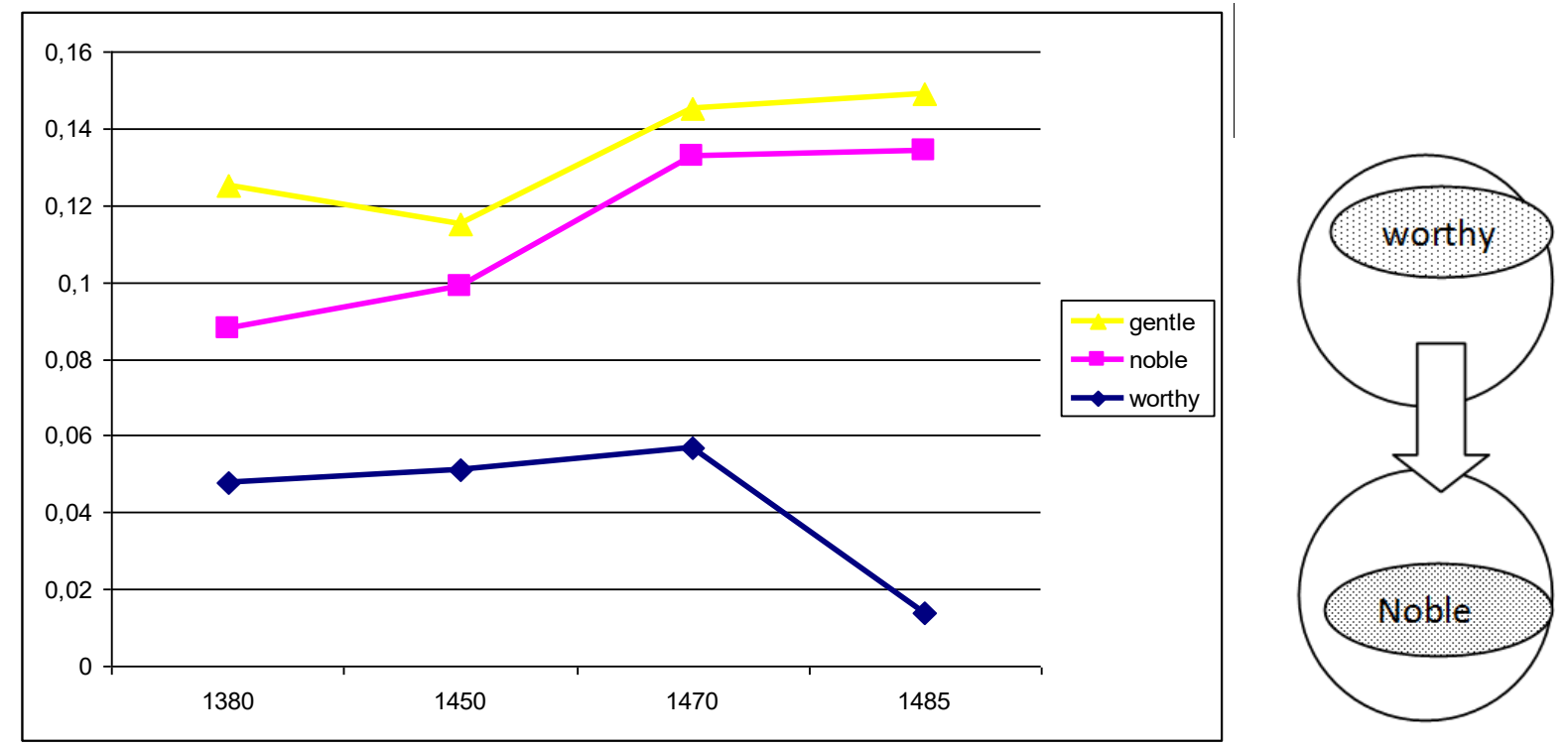

Figure 2. A comparative frequency analysis of words in "Canterbury tales" (1380), "Stanzaic Morte Arthur" (1460/70), "Merlin" (1450), "Le Morte Darthur" (1485) showing how the adj. noble becomes a central member of the category

The line of changes revealed in Fig. 2 could be explained as moving backwards compared with the traditional linguistic description: from a meta-metasemiotic level the level of the most abstract ideas evolving about the ethical-cultural-axiological system of knighthood - to a metasemiotic level (the level of the text and discourse) and only then to a semiotic one. Benveniste put forward an idea as following:

"Language is the only system with its meaning articulating itself in this way in two dimensions. The other systems have monodimensional meaning: either semiotic (gestures of politeness; mudras) 
without semantics, or semantic (artistic expression) without semiotics. It is the privilege of language to carry at the same time the meaning of signs and the meaning of enunciation. This gives its major power to create a second level of enunciation at which it is possible to consider (tenir des propos) meaning meaningfully". This is its "metalinguistic" capacity (II, p. 65)" (cit. Sandor 1989: 48).

The semantic transformations are driven by both: changes in the conceptual representation shaped within the social and cultural systems as well as the existing linguistic units.

Given the major trends revealed by a general frequency analysis, we had to go into what was going on in the romances in question with the two romances studied carefully. Geoffrey Chaucer's work is beyond the scope of discussion in the present paper, for it is a complicated case of several genres combined as well as several speakers of various social background. The tales by people with aristocratic origin largely indicate similar processes (Komova \& Sharapkova 2017).

The dataset from both romances was manually annotated for major meanings, generally formulated on the basis of the text itself keeping in mind three types of knighthood proposed by Kennedy. Four rather recurrent semantic invariables stable for both texts could be generally grouped around: 1) war, 2) morality, 3) behavior, 4) class. All the other shades of meaning were determined by the context and content of the romance and are discussed separately in each section.

\section{Back to the balance lost: new moves of the lexical category in "Merlin"}

In this part of the paper we'll look more closely at the prose romance "Merlin or the early history of King Arthur" (1450). In this section references to the pages of the romance are given in brackets. The immediate context of the major meanings of the adjectives worthy, noble, and gentle gives us a more detailed picture of the semantic changes mechanisms in this lexical category. The romance "Merlin or the early history of King Arthur" is considered to be the earliest piece of Arthurian literature written in English prose and as compared with Malory's original work "offers a straight-forward 
and fairly accurate translation into English of a single source, the Merlin section of the Old French Vulgate Cycle" (Conelee 1998).

\subsection{The semantic analysis of noble, worthy, and gentle}

The adjectives are used in similar collocational contexts naming people, e.g.: man, knight, duke. We should mention that gentle exhibits some interesting peculiarities. The text reveals a pronounced interchangeability of the words noble and worthy in the majority of contexts, probably accounting for the interference from French (as a source for translation) dominating and pushing out the already existing gentle and worthy in these settings.

Table 2. Collocations of noble and worthy in the romance

\begin{tabular}{|c|c|}
\hline 1)Than a-corded alle the noble men and wise & He that was a noble knyght and wele a-vised \\
\hline 2) A full noble knyght, and was also a felowe of & - thei heilde hym worthy and wise; \\
\hline the rounde table & The worthy men of the rounde table; \\
\hline 3) A right noble man and a trewe - that were & Full worthy men and right trewe; \\
\hline ad right gode knyghtes and trewe. & Alle the noble men of thi londe \\
\hline 4) All & the o \\
\hline
\end{tabular}

As far as the correlation between meanings and words is concerned, in some cases it was easy to decide what type the word refers to, while in some cases it was impossible even with regard to a more extended context. Diversification of senses turned out to be especially complicated in collocations with noble knight, worthy knight and gentle knight: he was a lorde and maister, and a felowe of the rounde table; and it was goode reson, for he was a noble knyght, and a trewe and full of alle vertues and goode tecches (good traits of character), and the moste curteise knight (463). In the following example, we clearly observe the meaning of a class affiliation profiled: 1) he was a noble knyght, and right nygh cosin to the kynge (244). Hereafter, we propose to annotate those cases when even a broader context failed as a "combination of senses" or just a "knight" (see Fig. 3). 


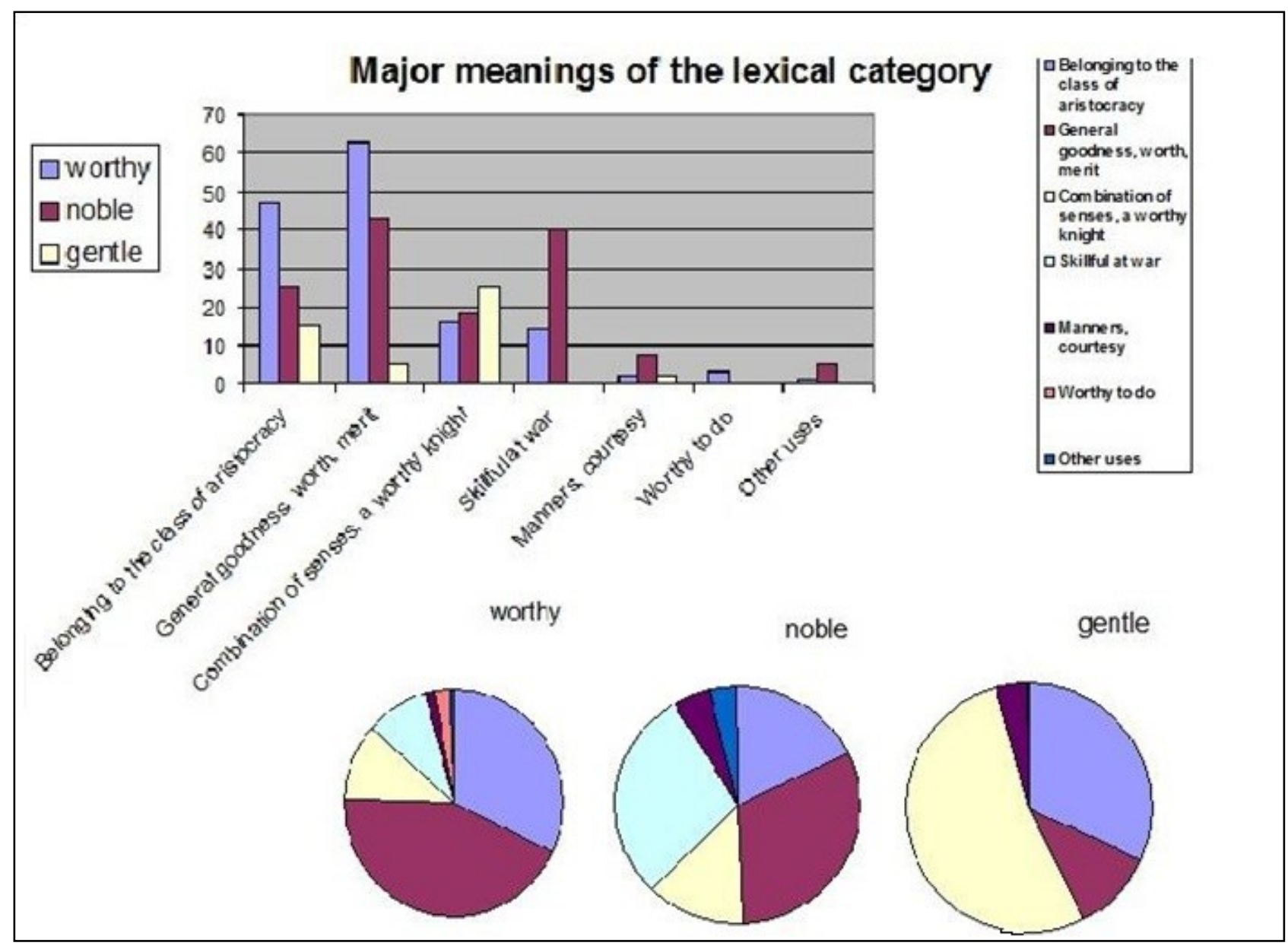

Figure 3. Comparative analysis of senses of worthy, noble and gentle in "Merlin" (1450)

The analysis demonstrates that the meaning "belonging to aristocracy" occupies a substantial part in all the three words, but "general goodness" is more prominent in worthy. Besides that, studying all contexts in the romance proves worthy to take over other words within the category, as it is used more frequently in the context of a particular discourse area describing honest behavior, goodness and merit without any further specification. Noble compared with worthy, is equally frequent but exhibits variation of shades of meaning illuminating greater polysemy and becomes closer biased to the knighthood concept taken in its typological variety. Consequently, we see that the type of a warrior sense is pronounced in both with noble taking the lead over worthy. We can find the combination of senses - in gentle. Still, compared with noble and worthy, the adjective gentle is predominantly used in the direct speech of knights and in exclamations: A noon the kynge cryed with high voys (the king cried in a high 
voice), "Gentill knyghtes, now as armes, for now shall be shewed youre worthynesses!" (244).

\subsection{The conceptual analysis of noble, worthy, and gentle}

We observe that the split of the meaning in some contexts follows new tendencies fixed in this text for the first time in English literature. A small but very important fraction of contexts where noble is combined with non-human objects opens up new possibilities for semantic transfer as the adjectives find ways to go beyond the anthropological category and step into the outer inanimate world (see Fig. 3). As a result, we have at our disposal the necessary factitive data of changes in the meaning that serve as a key to a better understanding of the worldview during a certain period in a certain place, the latter allowing linguistic facts to be further categorized and conceptualized. The collocability of the lexemes noble and worthy in terms of moving through various categories could be represented in Fig. 4.

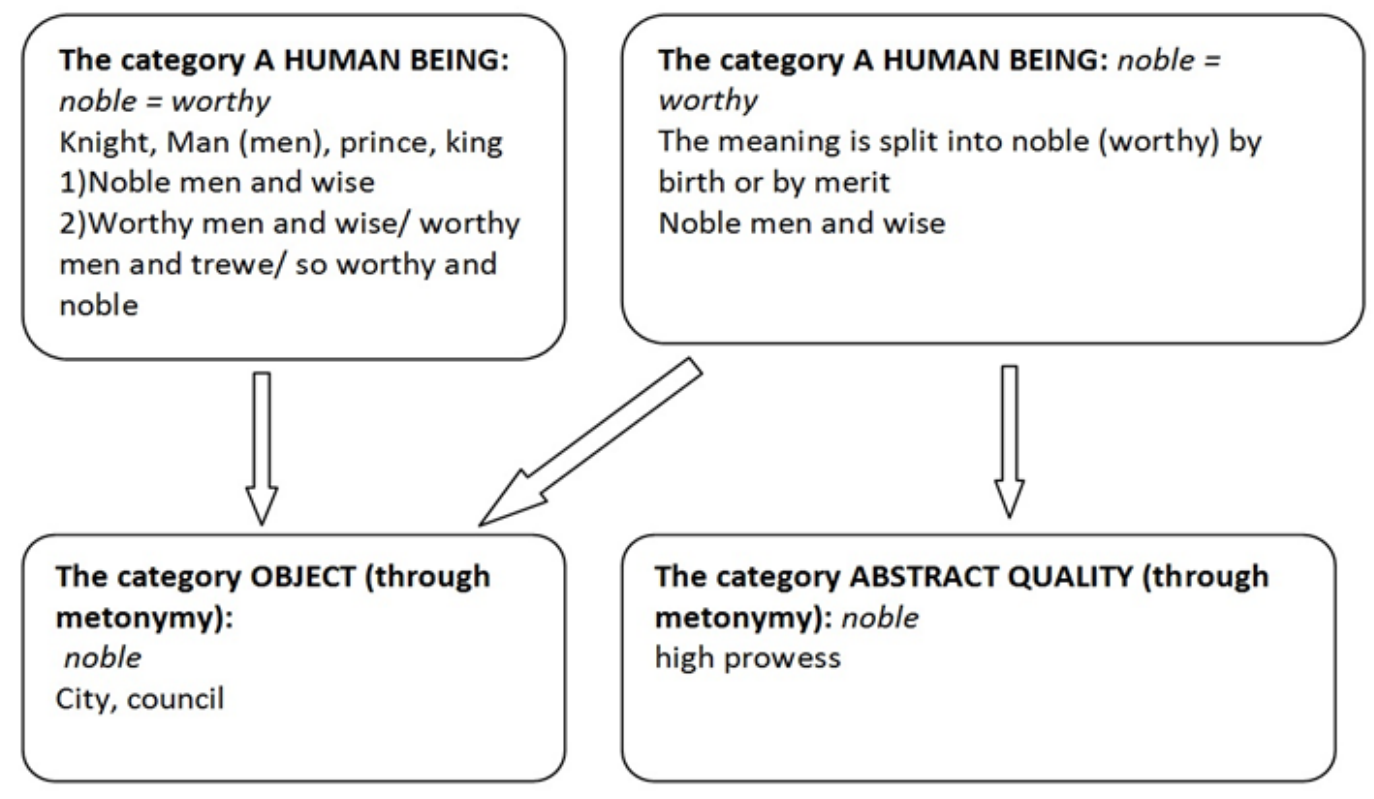

Figure 4. Development of the meaning of noble (adjective) in "Merlin" (1450)

The development starts from the category of "a human being" and then we have a split of the category into a man noble by birth and then by actions and thoughts, thus being projected to a spiritual domain. The set of domains is ontological, to the extent that it constitutes a basic map of regions in the human 'life-world': perhaps a natural domain, 
a cultural domain, and a spiritual domain (Brandt 2004: 22). Further on, through the processes of metonymy (a noble city, a noble council) and abstraction of qualities we get noble prowess - a 'must-have quality for a knight' (Fig. 4). The analysis of "Merlin" demonstrates that noble is making first steps towards the central position within the category attaining extra significance, for it makes up novel semiotic bonds. It keeps in accordance with Collazos, claiming that "signification emerges when an agent updates a response or a set of responses" (2016: 87-88). Thus, the contextual forces push the development of novel cognitive and semantic representations.

\section{The balance shifted: noble reclaiming salience}

Now let us turn to the category of nobility in "Le Morte Darthur" by Thomas Malory (1485), where the adjective noble is far more frequent than in other texts and as compared to other lexical units. This word serves as a manifestation of knighthood and literally perfuses the book about great knights from cover to cover even appearing in a subtitle: "King Arthur and his noble knights of the round table". It also brings the whole story to its noble end as well: Thus endeth thys noble and Ioyous book entytled le morte Darthur. Notwythstondyng it treateth of the byrth, lyf and actes of the sayd kyng Arthur of his noble knyghtes of the rounde table (862 In this section and further the references to the pages of the novel "Le Morte Darthur" are given in brackets). No surprise that this adjective used so many times was considered highly ambiguous, yet "the most important thematic phrase of the Morte Darthur" (Field 1971: 76). Consequently, within the context of the novel and in the cultural context, this adjective amounts to a meta-semiotic function as it drifted from "denotative semiotic to connotative semiotic" (Hjelmslev 1969: 114).

\subsection{The semantic analysis of noble, worthy, and gentle}

The adjective noble is used in a number of meanings: King Arthur is noble, his deeds are noble, the knights are noble, the realm of Britain is noble. It is easy to jump into a generalization that the whole world of knighthood is noble, however diverse it may be. Contrasted to the prose romance "Merlin", the work of Malory relied on a number of 
sources and was neither fully translated nor compiled, but written to embody a new understanding of the famous myth about King Arthur. So, if we remarked cautiously that the rise of noble in "Merlin" might partially owe to the French influence, here we may definitely point out that noble has acquired its proper place within the English language resulting in its overarching importance within the category under scrutiny.

Given the dominance of noble all other adjectives are significantly less frequent and subsequently give up in the competition for the central position within the category. The adjective worthy becomes grounded syntactically and is used in the construction worthy to do something and completely loses once apparently emerging sense of manners and courtly behavior. It is still used in the meaning of general goodness and merit, but the idea of gentle birth drops significantly if we compare with "Merlin" (Fig. 5). It also collocates with noble forming etymological doublets (Аракин 2007: 27), extremely popular at that stage of language development and used by many authors to facilitate reading: noble and worthy/ noble and mighty/ a noble knyght and a mighty $\underline{\text { man. }}$.

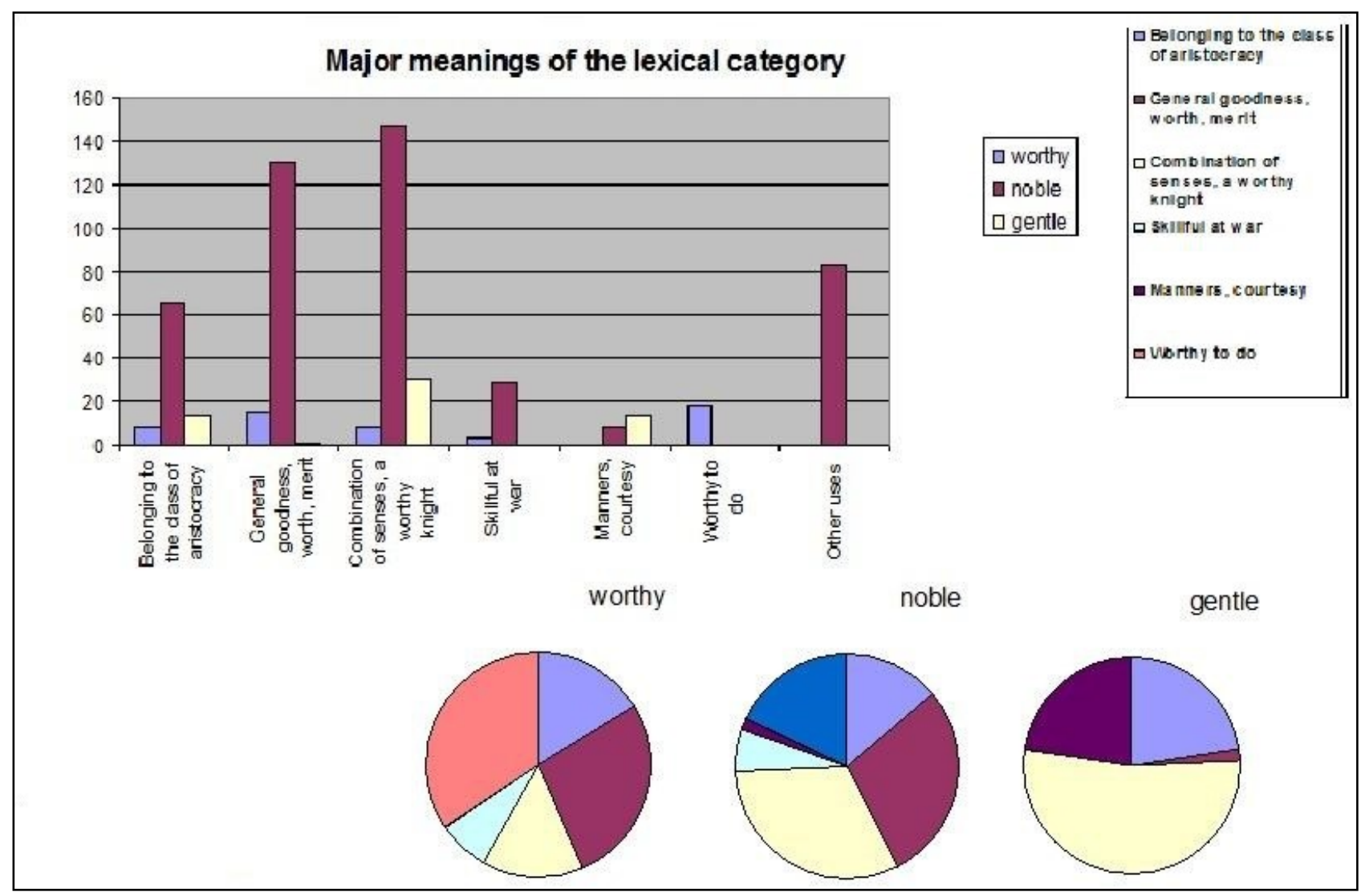

Figure 5. Comparative analysis of senses of worthy, noble and gentle in "Le Morte Darthur" (1485) 
The adjective gentle takes up the meaning of gentle birth and is found in the contexts focusing on aristocratic lineage but mainly in formulaic exclamations (Fig. 5) Reading into the up-bringing of a knight the adjective gentle acquires a semantic innovation. It starts to denote proper manners of a man at courtly service: For he that gentyl is wylle drawe hym vnto gentil tatches and to folowe the custommes of noble gentylmen (278) (For that is so gentle that will draw him unto gentle features, and to follow the customs of noble gentlemen). This innovation is further preserved in the image of a gentleman of future centuries (Zalesova 2009) and gives rise to a contemporary meaning of "kind and careful in the way you behave or do things, so that you do not hurt or damage anyone or anything" (Longman dictionary online). Courtly life, ideals of courtesy, and well-taught manners become much more foregrounded and the understanding of nobility gradually becomes advanced and elaborated and courtly behavior more significant: e.g. thêne the kyng aualyd his vyser with a meke \& noble coūtenaūce (182) (Then the king lifted his visor [of the helmet] with a meek and noble look).

Noble is characterized by a whole set of semantic shades including noble birth and various knightly qualities as well as numerous objects of the knightly world. What is more significant, as we have already mentioned - it becomes a prime word for the category. We should note that the semiosis of a single word could only be studied in sets or fields that correspond to mental entities for "individual words acquire their meaning through their relationship to other words within the same semantic field" (Rundblad \& Kronenfeld 2003: 68). Thus, if one word within the field extends its meaning it would "automatically narrow the sense of the neighboring words" (Rundblad \& Kronenfeld 2003: 68).

The adjective noble acquires new shades of meaning in new communicative contexts. It means that it "retains only a small part of the value it has as a sign" (Sandor 1989: 46) and becomes a word in a given sentence, the content plane of which is the intenté (Benveniste 1979, II: 54, 225) or the purport (Ахманова 1979:8). Then due to cognitive mechanisms the new balance between the form and meaning in the most 
general sense is settled. More precisely, both the cognitive representation and the semantic one are reorganized that calls for new semiotic bonds.

So, dividing the contexts according to the scheme presented above failed to display the essence of semantic innovations, for the group of 'other uses' is rather substantial (Fig. 5). A new proportion of contexts gives credibility to further discussion of the changes based on a collocation capacity (syntagmatic as opposed to paradigmatic or comprehending as opposed to recognizing a sign) and the application of a cognitive approach to semantic categories description and interpretation.

The idea of "gentle birth" is naturally prototypical for a noble knight and further supported and extended in collocations with lord, king, and lineage: he is come of a noble blood and of kynges lygnage. Thus, it is not surprising that one of the most frequent collocations with noble is noble blood, though it still signifies the transference from a distinct human being to a more abstract domain, combining various types of now described as: comen of a noble blood. Not only the individual nobility is outlined but a representation of a lineage or a family gets value: for that lady was bothe good and fayre (fair) and a woman of noble blood \& fame (329). This conceptualization is further stretched to objects from knights' surrounding world: the land, the family, the house, the name: the knyghte is good \& come he is of a noble hous. In these contexts noble is once replaced with worthy: came oute of soo worthy an hows.

In some contexts the adjectives noble and gentle are interchangeable and paradigmatically very close to each other: 1) cam neuer but of a gentyl blood. 2) I am a gentyl man borne and of more hyghe lygnage than thou. The adjective gentle in the text of Malory is mainly used in the meaning pertaining to aristocracy thus being analogous to noble in this sense. Thus, the collocation allows blending and the new socially marked term is formed - a gentleman, who could be in its turn characterized as noble (noble gentylman). The adjective noble is somewhat formulaic in this context 
and also points at a set of certain "admirable qualities" imposed on this new social type arising in the historical scene.

The main focus of Malory's writing is building up the knightly world, so he actively works on forming a new system of loyalty based on the oath of fidelity. At the same time, the older and more archaic system, which was relying on a kinship fidelity to the lord, is now ousted to the periphery (Gravett 2008). By means of the obligatory oathtaking the formerly independent free men were turned into fiddles of a king with extra ideas of a 'good knight'. They continued to be called free, but the very basis of freedom had been transformed: independence had been replaced by dependence according to the law and its practices regulated by various rules with the ruler now being the granter (Ford, 1992: 47). So first, we find the examples with special attention to a good lineage and noble blood, and then these two ideas get mingled together with the oath of fidelity: 1) rather than I shold shame myn othe \& my blood I wille hold my way what soo euer falle therof (503). Being of noble blood is no longer enough to be noble and fidelity is among the most valued virtues of a knight in literature: "after feudalization freedom meant service on behalf of a king who was the only possible authority in the new state" (Ford 1992: 57).

Context-based study procures deeper insight into the way knighthood as a social concept worked and shows that nobility is not a thing-meant in itself, but a socially grounded name/sign for the quality. It is indirectly proved by contexts where noble is used with verbs of cognitive processes of knowing, getting to know (wete (witen/witan), knowe or understand). Knights either know that a person in front of them is of noble blood or assume that it is so: For euer me thou3te ye shold be of a grete blood (219). The latter example is taken from the scene, where Launcelot agrees to knight Gareth, living and serving as a kitchen servant at court and not yet disclosing his real identity: ye shal ryght wel wete that he is comen of a ful noble blood and as for his myghte and hardynes ther ben but fewe now lyuynge that is so myghty as he is and so noble of prowesse It semeth by yow said kynge Arthur that ye knowe his name 
and fro whens he is come / and of what blood he is I suppose I doo so said Launcelot (242).

\subsection{The conceptual analysis of noble, worthy, and gentle}

In the romance "Le Morte Darthur" noble fulfills an axiological function: it defines and evaluates knights, maps them into a new system and drives them to perform certain deeds leading to worship, fame, glory. The binary system of opposite values guided lives of knights with reliance on numerous manuals of the age (including romances) providing clear instructions on how to gain worship and avoid shame. Consequently, a metasemiotic shift in the meaning of "having admirable qualities" was first applied in the community to knights and then through metonymy to their deeds, acts and generally - behavior. The semiosis of noble starting with a category of "a human being" conquered new spheres of human experience: material space, fictional universe, actions and abstract notions, thus entering the cultural and spiritual domains of human experience (Brandt 2004). Notably, if at the beginning of the Malory's text prowesse, deeds, might, mercy go hand in hand with the description of a noble knight - noble knight of prowess, at the end we find all these entities described as noble themselves (noble prowess/noble deeds). Thus, the semantics of prowess as an attribute of a noble knight was transformed into a linguistic sign detached from its semantic base or a thing detached from its owner: a ma of the most noble prowess. All the new categorial innovations based on collocations are represented in a graphic form (Fig 6). 


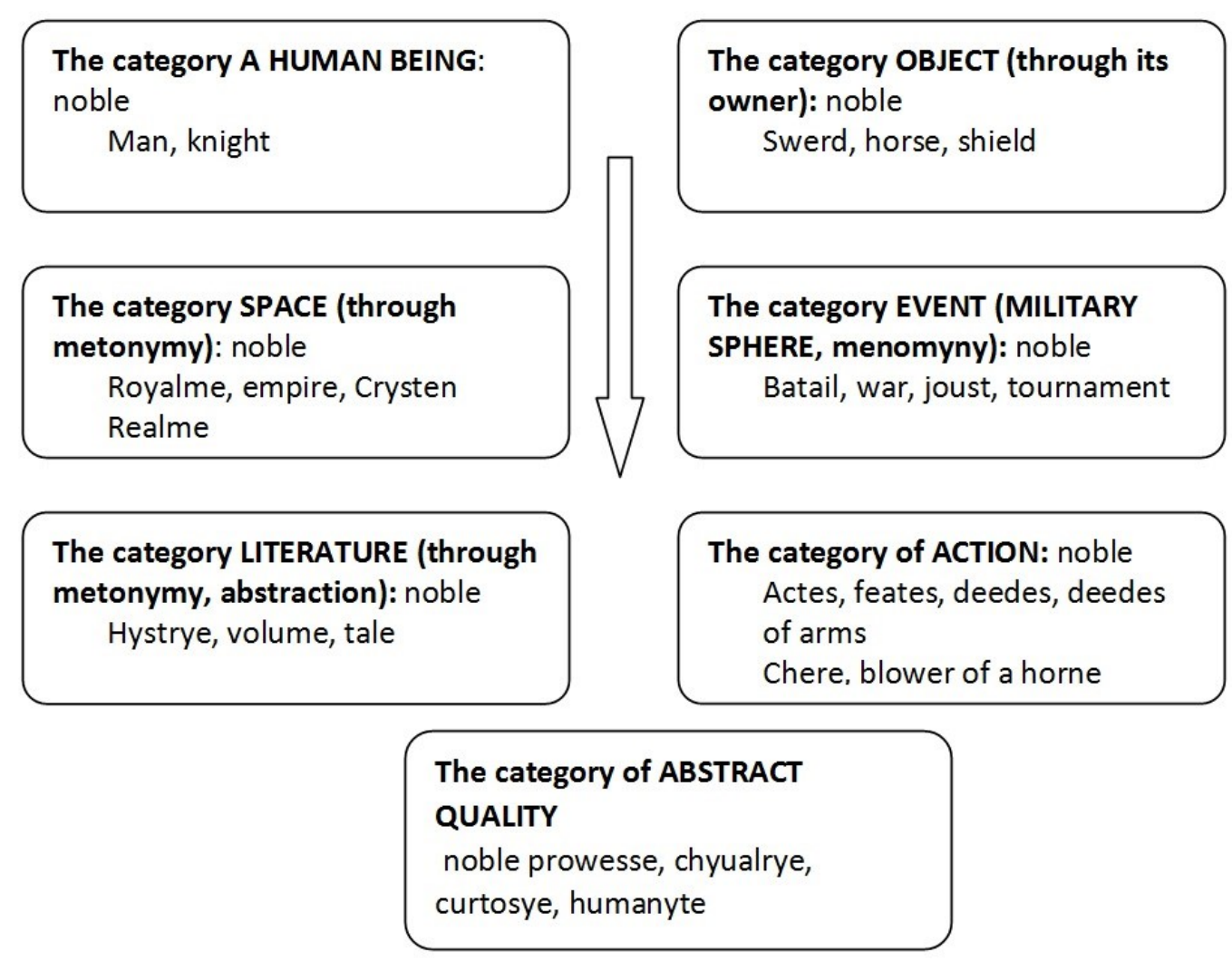

Figure 6. Meaning development of the adjective noble in "Le Morte Darthur" (1485).

We can conclude by hoping that the architecture of certain semantic categories is socially and thus invariably historically-culturally grounded albeit following fundamental pathways of reasoning: metaphors, analogy, contrast, or metonymy.

"It seems [...] clear that any kind of Platonian realism in linguistics is doomed to failure and that speech communities create their own conceptual systems, or in other words: a "world" of their own, which is then subsequently verbalized. This is to say that concepts are neither universal nor are they really language-specific: they rather are culture-specific and thus extralinguistic phenomena" (Blank 2003:8).

The historical semiosis demonstrates that the adjective noble is transformed and recategorised in the medieval texts through increasingly abstract conceptualization of nobility and knighthood being gradually complicated and brought to a highly abstract domain of knowledge. We cannot agree more with what Uspensky wrote in his "History and semiotics" stressing the fact that in a semiotic perspective a historical process is interpreted as a communication between the given and the new information, an individual and society etc., in fact a new meaning is perceived and interpreted in "the system of public (social) conciseness" (Успенский 1994: 10-25). 
Noble birth lying at the very kernel of the category is still preserved verbalized by an extended set of collocations (noble blood, lineage, kin, house, family), but the whole system of attributes is more diversified and not the entities, but the actions come to the fore (prowesse, noble deeds, acts). The behavior of a knight perceived as noble included bravery and prowess, mercy and kindness, ability to rescue a damsel and reach for the Holy Grail, and we remember that only a knight with a soul pure and noble was able to aspire and see it. Finally, we claim that the periphery of this category is becoming more and more profound and finally more salient than the core. Noble behavior, curtsey, and moral qualities having no direct correlation with birth however noble it might be, take the lead: noble chyualrye, curtosye, humanyte, frendlynesse, hardynesse, loue, frendshyp. To put it more clearly, this semantic transition signals not only the semantic change, but also the transition from a sign of language system to the process of acquiring significance within the axes of contexts and finally becoming a sign of social status and culture. The word of high cognitive complexity and culturally marked is therefore acting in three systems: semiotic, metasemiotic, and metametasemiotic - and exhibiting various peculiarities at each level.

\section{Morphological derivation in strengthening major semantic pathways}

By and large, the hypothesis that the concept of knighthood lies beneath all the semantic changes of words within the category of nobleness is further confirmed through morphological derivation of the adjectives studied. They are further recategorized in terms of parts of speech. Parts of speech do not only pertain to linguistics, but as recent neurological research suggests occupy different subregions within the semantic network (Binder et al. 2009). They turned out to be associated with "knowledge of actions, manipulable artifacts, abstract concepts, and concrete concepts". Since we proceeded from the conceptualization of a knight to its inexhaustible quality and observed how the quality changes along with the transformations of the object it is anchored to, we now need to identify if any of these changes are further 'sedimented' and fixed in the new nouns to evolve. 
The words of the semantic category of nobleness under investigation open a class of newly formed nouns. The first class to be outlined is returning back to the anchoring object, either narrowing down the scope of application or extending it. We get worthies in a set phrase "nine worthies" to designate a limited group of the greatest men in the world's history, prime models for young knights, which apart from fiction survived in sculptures of gothic chapels: Whether those worthies belong to the same stock we have not examined [CME $\mathrm{P}$ and $\mathrm{V}]$; These were the iiij estates with alle the ix worthies [CME $\mathrm{P}$ and $\mathrm{V}]$. The adjective gave a name - worth for a worthy person belonging to the upper class and a noun embodying the abstract ideas of good nature and honest behavior. To a similar pattern belongs gentleman from the adjective gentle.

A more interesting case arises when an abstract concept gets formed - worthynesse (worthynes): yf ye be of prowesse and of worthynesse ye shalle be a knyght of the table round (104).

Worshyp as a noun belongs to the family of words, yet was formed already in Old English from worðscip, wurðscip(Anglian), weorðscipe (West Saxon) (OED) and developed its semantics according to what the socio-cultural situation demanded. This quality is of paramount importance for the chivalric framework as it was gained in combat and tournament. Probably the predominantly war-like contexts work for preserving a military component in the adjective: sory said Merlyn for I shalle dye a shameful deth / to be put in the erthe quyck / and ye shall dye a worshipful deth (68). However, this notion was still strongly influenced by ethics of knighthood and murderers rarely got the title of a worshipful man no matter how many lands they got and whatever they did. A murder is an act of killing not in a battle field and not following the rules of tournament: Soo that day syre Palamydes had grete worship (288). 
Still, as noble becomes the central and the sample representative of the category, its varying morphological composition sheds light on further conceptual derivation and proves the reality of the types of knighthood suggested by Kennedy: the warrior, the moral, Christian knight, and the knight-courtier. Noble turns out to be a lexeme representing the conceptual domain of knighthood on a somewhat reduced scale. It vividly reflects the history of the English people, especially when being a loan-word it becomes 'naturalized' and 'assimilated'. It further gives rise to some nominalderivatives that in the language correspond to abstract notions starting with but not limited to qualities of a well-born person.

First of all, we should mention the coins of special purity called nobles, for they were made from gold - the noble metal. This is probably the only instance where the primary meaning of price once notable within the category remained: So that ye offre nobles or sterlynges [CME P and V]. Still other nouns, like noblesse, nobleness and nobley, varying in their semantics appeared. According to the etymological dictionary, noblesse appeared in English simultaneously with an adjective dating back to French influence, but noblesse is kept in language only in the phrase noblesse oblige, borrowed from French for the second time in the middle of the XIX century.

In the Medieval literature noblesse was very frequent and was used to denote this elevated concept of noble spirit. Your vertues al and yowre hie noblesse [CME P and $\mathrm{V}]$; To loue with good corage (strong courage), it cometh of noblesse of herte [CME P and V]; for a man of your bounte and noblesse shold not be without a wyf (59). In the second example the meaning of nobility is reinforced by the other noun - bounte that meant goodness, virtue, valour [MED]. Noblesse and noblenesse are nouns following similar derivational patterns: the first one employs a suffix of the Roman origin and the second one the suffix of the Germanic origin (the first one to form hybrids with words of the French origin). The coexistence of two nouns in close contexts may account for the system of morphological elements in the middle of change further complicated by French suffixes brought together with borrowings. Still, studying "Le Morte Darthur" 
by Malory shows some subtle functional difference. The first one is used to denote abstract notion of knighthood, while the second the abstract quality of a knight, being described in this particular context: here maye ye here the noblenes that foloweth sir launcelot (317).

There is one more derivative to be mentioned: nobley. It is in agreement with the court system and in accord with the new needs and requirements of the speakers within society at large. This noun described the acts held with appropriate splendor, richness, and courtesy. These are illustrious, luring and grand tournaments, jousts, and king's feasts: 1) And anone they were rychely wedded with grete nobley_(333) (And they were richly wedded with great noblesse); 2) And thenne Arthur made sir Tristram knyght of the table round with grete nobley and grete feest as myghte be thought (423) (And then Arthur made sir Tristram a knight of the Round Table with great noblesse and made a great feast as great as it could be thought of).

By and large, adjectives of this category (noble...) are signs of mental representation of qualities of objects, including human beings as subjects and objects of the process of viewing, recognizing, and naming something as new and separate from what has become already well known. Metaphysically the problem of 'thingness' (veshchnost' Toporov 1995: 8-9) is solved by the semantic evolution in words. Adjectives functioning at first as names representing things' qualities and then nouns fortifying the dynamic flux into more abstract and rigid structures illuminate both: the natural stages of semiosis in language and most archetypical cognitive processes. In terms of semiotics/semiology adjectives are primary, linear and thus - dynamic signs. Their semantic derivative (nouns) emerges later and incorporates more than one specification of the "thing" named. The sign thereby evolves through various levels of semantic transition either expansion or extension.

This idea was first formulated by Pierce through a famous metaphor of growth of a sign: "Thought $[\ldots]$ is in itself essentially of the nature of a sign. But a sign is not a 
sign unless it translates itself into another sign in which it is more fully developed. [...] Thought must live and grow in incessant new and higher translations, or it proves itself not to be genuine thought" (cit. Nöth 2014: 175).

Though we mostly rely on the Saussurean framework of a linguistic sign, which is made up of signifié and signifiant, and fully understand that blending of Saussurean and Pierce's conception is hardly possible due to the basic differences of two trends of semiotics. However, the necessity of anthropocentric element, the practical necessity to study meaning as a dynamic concept makes the idea of sign growth very attractive and explanatory and very fitting to the cognitive framework.

\section{Conclusion}

To reiterate: language is commonly assumed to represent a system of signs in terms of oppositional description, and each linguistic unit is outlined and described as the unity of expression and content, form and meaning, and finally, meaning and function. However, this mirror-like static relationship is constantly 'violated' in speech and through speech, almost never having any other form of existence. This is because language is a "fragile assemblage of local mechanisms, inseparably related to a much broader network of expressive and cognitive instances grounded in those parts of neural architecture that cooperate in creating the yields of consciousness" (Brand 2004: 17). The language development is complex and the paths along which a form gets its meaning are diverse and semiotically mediated, as it was demonstrated in the present study. Still, the complexity could be subdivided into much simpler components for heuristic purposes and each component scrutinized separately. We put forward, that to incorporate the semiotic perspective into the cognitive linguistic framework we need to differentiate the levels of: cognitive representation, semantic representation, and the linguistic one. The semiotic bonds get formed between these levels and further transformed through the action of contextual forces. These forces can be either individual or social and work together. The changes at any of the levels result in the 
semiotic bonds being reorganized and relived, thus affecting various levels of understanding.

Semantics, syntactics/syntagmatics and pragmatics are said to be highly plausible in terms of semiotic description of the above mentioned linguistic phenomena (noble being the root notion of the concept), for the major reason for meaning development should be sought in the fundamental necessity to capture and communicate a piece of the world. Sign is the most abstract form of representation for various and variable speech phenomena - words, word combinations and their equivalents - true representatives of the process of encoding our mental lexicon and its decoding in the process of verbal/mental elicitation, interaction, and empathy.

Consequently, the process of meaning construction through categorization or even more globally - semiosis - proceeds at the crossroads of society and culture where literature plays one of the influential roles not to be overlooked by linguistics and semioticians. The long tradition of philological analysis and literary criticism scaffolds cognitive analysis of lexis and quantifying corpus analysis with literary, cultural and social background that can bring solid evidence to preliminary quantitative data and explain the direction of these contextual forces. Therefore, certain pathways lexical units choose to go are outlined with greater precision.

The lexical units analyzed above come forth as historically charged sings of language (their etymological background is 'factitive' in terms of their spatial-temporal lexicographic anchorage), they are socially biased (as signs of social hierarchy roles and relations) and they become idealized, stereotyped and mythopoetically transferred 'fictive' signs of cultural empathy.

The dominating adjective noble of the category went through several stages: first, after it was fully assimilated in the language, it obtained salience within the category (revealed by frequency analysis), then it united all the possible meanings existing 
within it, thus pushing the other members to the periphery, third, being a social and cultural sign it finally changed its meaning from "renowned, of superior birth" to "having high moral qualities". It marked the semiotic transition from the older to a new feudal system, that is why we have chosen works, devoted to the knighthood system, although the texts of religious character may also reveal some nuances to be looked at. Adjectives worthy and gentle also formed new semiotic bonds and occupied novel places within the category of nobility. The gradual abstraction and disembodiment of noble and other lexical items as linguistic signs lead to a rather complicated conceptual image of chivalric nobility since it had been re-categorized under the influence of socio-cultural changes. Nobility and knighthood as the conceptual entities gradually became more complex bringing forth a highly abstract field of knowledge enriched by derivative nouns, blended in the same conceptual domain of knighthood.

As the domain of knightly qualities being the social and cultural construction of the time becomes more and more elaborated, and a more diversified lexical picture emerges. We would like to suggest that the idea of historical-cultural semiosis holds true for the lexical categories of profound emotional value and attractiveness thus becoming "cultural" signs for millions of speakers of English and attracting novel concepts and ideas. The words themselves exist in a constant state of flux triggered by socio-cultural changes and mutual relationship of words within a category organized through a radial category. The elements at the core and periphery zones migrate and either obtain salience or become insignificant. So, the more salient the word within a category becomes, the bigger and vaster the changes would be. Still only the words, going beyond the original narrow semantic domain and social setting get the chance to be preserved and developed by a language system through centuries. The presence of a human and their socially determined, situated cognition in language is becoming a particularly relevant issue for the linguistic analysis of words and their meanings. At the end of our paper we would like to cite the words by Hjelmslev: "Language - human speech - is an inexhaustible abundance of manifold treasures. Language is inseparable from man and follows him in all his works. Language is the instrument with which man 
forms thought and feeling, mood, aspiration, will and act, the instrument by whose means he influences and is influenced, the ultimate and deepest foundation of human society" (1969: 3).

\section{List of abbreviations}

B\&T - Bosworth-Toller Anglo-Saxon Dictionary

MED - Middle English dictionary

OED - Oxford English Dictionary

\section{Notes}

1. Heine stressed that "language is a historical product and must be explained first of all with reference to the forces that have shaped it" (Heine 1997:74). Challenges and potential benefits from investigations of diachronic problems are discussed in greater detail in "Historical semantics and cognition" (1999), "Words in time: Diachronic semantics from different points of view" (2003) and finally explicitly stressed in Geeraerts (2016).

2. Compare: "A gradually increasing emphasis on the description of cultural phenomena as the outcome of individually (or communally) articulated social sign systems led to the burgeoning currency of schools in cultural analysis associated with cognitive trends in cultural anthropology" (Cobley \& Randviir 2009).

\section{Acknowledgements}

I would like to thank Prof. Larissa Manerko for providing theoretical insights and thoughtful suggestions to the manuscript on the stage of its preparation. I am also grateful to Grigoriy Markevich and Dmitry Zlenko for technical assistance.

\section{References}

Akhmanova, O.S. \& Idzelis, R. (1979). Linguistics and semiotics. Moscow. Moscow University Press. 
Arakin, V.D. (2007). Essays on the history of the English language. Moscow: FISMALIT. / Arakin V.D. Ocherki po istorii anglijskogo jazyka. Moskva: FIZMALIT. / Аракин В.Д. Очерки по истории английского язика. Москва: ФИЗМАТЛИТ. Ardila, A. (2016). L.S. Vygotsky in the $21^{\text {st }}$ century. In Psychology in Russia: State of the art, 9 (4), p. 4-15.

Baum, R. (1977). Emile Benvenistes Auseinandersetzung mit dem sprachtheoretischen Ansatz Ferdinand de Saussures. In Systemlinguistik und Sprechakt, IF, 82, p. 1-38. Beckner, C., Blythe, R., Bybee, J., et al. (2009). Language is a complex adaptive system: Position paper. In Language learning, 59, p. 1-26.

Benveniste, E. (1979). Problemes de linguistique generale, Paris: Collection Tel. Berdnikova, D. (2011). Nobility as a marker of mentality in Medieval England (based on Anglo-Scottish ballads). In Language and linguistic activity in the interdisciplinary space: a collection of articles of the international conference. Saint Petersburg: Saint Petersburg University of economics and finance, p. 111-114. / Berdnikova D. Znatnost' kak pokazatel' mentaliteta v srednevekovoj Anglii (na primere anglo-shotlandskikh skazok. In Jazyk i rechevaja dejatel'nost'v mezhdistsiplinarnom prostranstve: Sbornik statej po materialam mezhdunarodnoj konferencii: Sankt-Petersburg: SanktPetersburgskij Universitet ekonomiki i finansov, s. 111-114. / Бердникова Д. Знатность как показатель менталитета в средневековой Англии (на примере англо-шотландских сказок). In Язык $u$ речевая деятельность $в$ междисииплинарном пространстве: Сборник статей по материалам международной конференции. Санкт-Петербург: Санкт-Петербургский Государственный университет экономики и финансов, с. 111-114.

Baudouin de Courtenay, I.A. (1963). Selected papers in linguistics in two volumes. Moscow: The publishing house of USSR Academy of sciences. Vol. 2. / Boduen de Kurtene I.A. Izbrannye raboty po jazykoznaniju: $v 2$ tomakh. Tom 2. Moskva: Izdatel'stvo Akademii nauk SSSR. / Бодуэн де Куртенэ И.А. Избранные работы по языкознанию: в 2 томах. Том 2. Москва: Издательство Академии наук СССР. Biber, D., Conrad, S. \& Reppen, R. (1998). Corpus linguistics: Investigating language structure and use. Cambridge: Cambridge University Press. 
Binder, J.R., Desai, R.H., Graves, W.W. \& Conant, L.L. (2009). Where is the semantic system? A critical review and meta-analysis of 120 functional neuroimaging studies. In Cerebral cortex, 19 (12), p. 2767-2796.

Blank, A. (1999). Why do new meanings occur? A cognitive typology of the motivations for lexical semantic change. In Historical semantics and cognition, Blank, A. \& Koch, P. (eds.). Berlin-New York: Mouton de Gruyter, p. 61-89.

Blank, A. (2003). Words and concepts in time: Towards diachronic cognitive onomasiology. In Words in time. Diachronic semantics from different points of view, 143. Eckardt, R., von Heusinger, K. \& Schwarze, C. (eds.). Berlin-New York: Walter de Gruyter, p. 37-65.

Bosworth \& Toller Anglo-Saxon Dictionary. Available at: http://bosworth.ff.cuni.cz/ Brandt, L. (2008). Literary studies in the age of cognitive science. In Cognitive semiotics, 2 (Supplement), p. 6-4.

Brandt, P.A. (2004). Spaces, domains, and meaning. Essays in cognitive semiotics. European semiotics series, 4. Bern: Peter Lang.

Cobley, P. \& Randviir, A. (2009). Sociosemiotics. In The Routledge companion to semiotics. London: Routledge, p. 118-135.

Collazos, M. (2016). Design semiotics with an agentive approach: An alternative to current semiotic analysis of artifacts. In Meaning, mind and communication. Explorations in cognitive semiotics, Frankfurt am Main: Peter Lang, p. 83-99.

CONLEE, J. W. (1998). Prose Merlin. Kalamazoo, Mich, Published for TEAMS in association with the University of Rochester by Medieval Institute Publications, Western Michigan University.

Corpus methods for semantics: Quantitative studies in polysemy and synonymy, 43. (2014). Glynn, D. \& Robinson, J.A. (eds.). Amsterdam-Philadelphia: John Benjamins Publishing Company.

Clausner, T.C. \& Croft, W. (1999). Domains and image schemas. In Cognitive linguistics, 10, p. 1-32.

Duggan, A.J. (2000) Introduction. In Nobles and nobility in medieval Europe: Concepts, origins, transformations. Woodbridge: Boydell \& Brewer Ltd. 
Dummet, M. (1993). What is a theory of meaning? In The seas of language. Oxford: Oxford University Press, p. 34-93.

Eco, U. (1986). Semiotics and the philosophy of language. Bloomington: Indiana University Press.

Evans, V. (2009). How words mean: Lexical concepts, cognitive models, and meaningconstruction. Oxford: Oxford University Press.

Field, P. (1971). Romance and chronicle: a study of Malory's prose style. Bloomington: Indiana University Press.

Field, P. (1982) [2008]. Introduction. Le Morte Darthur the seventh and eighth tales.

The London Medieval and Renaissance series. Indianapolis: Hackett Publishing Company.

Ford, B. (1992). Cambridge cultural history of Britain: Modern Britain. Cambridge: Cambridge University Press.

Frank, R.M. \& Gontier, N. (2010). On constructing a research model for historical cognitive linguistics (HCL): Some theoretical considerations. In Historical cognitive linguistics, 47, Cognitive linguistics series. Berlin-New York: Mouton De Gruyter, p. 31-69.

Frege, G. (1948). Sense and reference. In The philosophical review, 57 (3), p. 209-230. Geeraerts, D. (2010). Salience phenomena in the lexicon. A typology. In Words and other wonders. Papers on lexical and semantic topics. Cognitive linguistics series, Berlin: Mouton de Gruyter, p. 74-96.

Geeraerts, D. (2016). The sociosemiotic commitment. In Cognitive linguistics, 27 (4), p. $527-542$.

Geeraerts, D., Grondelaers, S. et al. (1999). What's in a word: Lexicology. In Cognitive exploration of language and linguistics. Amsterdam-Philadelphia: John Benjamins Publishing, p. 25-50.

Goodwin, Ch. (2000). Action and embodiment within human situated interaction. In Journal of Pragmatics, 32, p. 1489-1522.

Gravett, Ch. (2008). Knight noble warrior of England 1200-1600. Oxford: Osprey Publishing. 
Halliday, M. (1978). Language as a social semiotic. London: Edward Arnold.

Harder, P. (2010). Meaning in mind and society: A functional contribution to the social turn in cognitive linguistics. Cognitive linguistics research [CLR]. Berlin-New York: Mouton de Gruyter.

Heine, B. (1997). Cognitive foundations of grammar. New York: Oxford University Press.

Hjelmslev, L. (1969) Prolegomena to a theory of language. Madison, Milwaukee, and London: The University of Wisconsin Press.

Jackendoff, R. (1983). Semantics and cognition. Cambridge: MIT Press.

Jackendoff, R. (2002). Foundations of language: brain, meaning, grammar, evolution. Oxford: Oxford University Press.

Kennedy, B. (1992). Knighthood in the Morte Darthur, $2^{\text {nd }}$ ed. Cambridge: D.S. Brewer.

Kennedy, E.D. (1994). The stanzaic Morte Arthur: The adaptation of a French romance for an English audience. In Culture and the king: The social implications of the Arthurian legend: essays in honor of Valerie M. Lagorio. Shichtman, M.B. \& Carley, J.P. (eds.). Albany: State University of New York Press, p. 91-112.

Komova, T.A. (1990). Modal verb in language and discourse. Moscow: Moscow University Press. / Komova T.A. Modal'nyj glagol v yazyke i rechi. Moskva: Izdatel'stvo MGU. / Комова T.A. Модальный глагол в языке и речи. Москва: Издательство МГУ.

Komova, T.A. \& Sharapkova, A.A. (2017). Worthiness or nobility? Semantic changes of the category of "NOBILITY" (based on "Canterbury tales" by G. Chaucer). In Akhmanov's readings, conference proceedings (December 23, 2016) Moscow State University, Moskva: Universitetskaja kniga, p. 44-59. / Komova T.A., Sharapkova A.A. Doblest' ili znatnost'? Izmenenija v semantike kategorii "blagorodstvo" (na materiale "Kenterberijskikh rasskazov" Dzh. Chosera). In Akhmanovskie chtenija, materialy konferentsii (Dekabr' 23, 2016). Moskovskij Gosudarstvennyj Universitet, Moskva: Universitetskaja kniga MAKS-press, s. 44-59. / Комова Т.А., Шарапкова А.А. Доблесть или знатность? Изменения в семантике категории "благородство" 
(на материале "Кентерберийских рассказов" Дж. Чосера). In Ахмановские чтения, материаль конференциии (Декабрь 23, 2016) Московский Государственный Университет. Москва: Университетская книга, с. 44-59.

Koubriakova, E.S. (1996). Concept. In A concise dictionary of cognitive terms. Koubriakova, E.S. (ed.) Moscow: Moscow University Press, p. 90-93. / Koubryakova E.S. Kontsept. In Kratkij slovar' kognitivnykh terminov. Koubryakova E.S. (red.) Moskva: Izdatel'stvo Moskovskogo Universiteta, s. 90-93. / Кубрякова Е.С. Концепт. In Краткий словарь когнитивных терминов. Кубрякова Е.С. (ред.) Москва: Издательство МГУ, с. 90-93.

Koubriakova, E.S. (1978). Parts of speech in the onomasiological framework. Moscow: Nauka. / Koubryakova E.S. Chasti rechi v onomasiologicheskom osveshenii. Moscow: Nauka. / Кубрякова Е.С. Части речи в ономасиологическом освещении. Москва: Наука.

Lakoff, G. (1997). Women, fire, and dangerous things. What categories reveal about the mind. Chicago: The University of Chicago Press.

Levinson, S.C. (1997). From outer to inner space: Linguistic categories and nonlinguistic thinking. In Language and conceptualization. Nuyts, J. \& Pederson, E. (eds.). Cambridge: Cambridge University Press, p. 13-45.

Lewis, C. (1960). Studies in words. Cambridge: Cambridge University Press.

Malory, Syr T. (1997). Le Morte Darthur. Ann Arbor, Mich.: University of Michigan Humanities. Print source: Le Morte dArthur Syr Thomas Malory, Caxton, William, ca. 1422-1491, Sommer, H.O. (ed.), b. 1861. London: David Nutt, 1889. Available at: https://quod.lib.umich.edu/cgi/t/text/text-idx?c=cme;idno=MaloryWks2

Manerko, L. (2016). Towards understanding of conceptualisation in cognitive terminology. In Lege artis. Language yesterday, today, tomorrow. The journal of University of SS Cyril and Methodius in Trnava. Warsaw: De Gruyter Open, 2016, vol. I (2), December 2016, p. 129-170. DOI: 10.1515/lart-2016-0012

Methods of cognitive analysis of word's semantics: Computer and corpus approaches. (2015). Zabotkina, V. (ed.). Moscow: Jazyki slavjanskoj kul'tury - translation. I Metody kognitivnogo analiza semantiki slova: kompjuterno-korpusnyj podkhod. 
Zabotkina V. (ed.). Moscow: Jazyki slavjanskoj kul'tury. / Методы когнитивного анализа семантики слова: компьютерно-корпусный подход. Заботкина В.И. (ред.). Москва: Языки славянской культуры.

Merlin: or the early history of King Arthur: a prose romance. (1997). Wheatley, H.B. (ed.). Ann Arbor, Mich.: University of Michigan Humanities Text Initiative. Available at: https:/quod.lib.umich.edu/c/cme/Merlin?rgn=main;view=toc

Middle English Dictionary. Available at: https://quod.lib.umich.edu/m/med

Mills, Ch. (1825). The history of chivalry or knighthood and its times. London: Longman, Hurst, Rees, Orme, Brown \& Green.

Nazarova, T.B. (1996). Linguistic and literary semiotics. In Applied semiotics / Sémiotique appliquée, 1 (1), University of Toronto, p. 19-28.

Nazarova, T.B. (1994). Philology and semiotics. Contemporary English language: A monograph. Moscow: Vysšaya škola. / Nazarova T.B. Filologiya i semiotika. Sovremennyj anglijskij jazyk: Monografiya. Moskva: Vysshaya shkola. / Назарова Т.Б. Филология и семиотика. Современный английский язык: Монография. Москва: Высшая школа.

Nietzsche, F. (2006). On the genealogy of morality. Keith, A. (ed.). Cambridge: Cambridge University Press.

Nöth, W. (2014). The growth of signs. In Sign systems studies, 42 (2/3), p. 172-192.

Quirk, R. \& Stein, G. (1993). English in use. United Kingdom: Longman Publishers. Oxford English Dictionary. Electronic edition. Ver: 4.0.0.1

Potebnya, A.A. (1999). Thought and language. Moscow: Labyrinth. / Potebnja A.A. Mysl' i jazyk. Moskva: Labirint. / Потебня А.А. Мысль и язык. Москва: Лабиринт. Rundblad, G. \& Kronenfeld, D. (2003). The semantic structure of lexical fields: Variation and change. In Words in time. Diachronic semantics from different points of view. Eckardt, R., Heusinger, K. von \& Schwarze C. (eds.). Trends in Linguistics. Studies and Monographs, (143). Berlin-New York: Mouton de Gruyter, p. 67-114.

Saussure, F. de. (1959). Course in general linguistics. New York: Columbia University Press. 
Sandor, A. (2015). Siginification, meaning, and the text level of language review and modification of Benveniste's theory of language and language use. In Indogermanische Forschungen, 94 (1), p. 45-66.

The concise Oxford dictionary of English language. (1993). Hoad, T.F. (ed.). Oxford: Oxford University Press.

The handbook of language emergence. (2015). MacWhinney, B. \& O'Grady, W. (eds.). Oxford: Wiley Blackwell.

Toporov, V. (1995). Myth. Ritual. Symbol. Image: studies in mythopoetics. Selected papers. Moscow: Progress. / Toporov V. Mif. Ritual. Simvol. Obraz: Issledovanija v oblasti mifopojeticheskogo: Izbrannoe. Moskva: Progress. / Топоров В. Миф. Ритуал. Символ. Образ: Исследования в области мифопоэтического. Избранные труды. Москва: Прогресс.

Tylén, K., Fusaroli, R., Bundgaard, P.F. \& Østergaard, S. (2013). Making sense together: A dynamical account of linguistic meaning-making. In Semiotica, 194, p. 3962.

Uspensky, B. (1996). Semiotics of history, semiotics of culture. Selected papers. Moscow: Yazyki russkoi kultury. / Uspensky B. Semiotika istorii. Semiotika kul'tury. Izbrannyje trudy. Moskva: Yazyki russkoj kultury. / Успенский Б. Семиотика истории, семиотика культуры. Избранные труды. Москва: Языки русской культуры.

Vennemann, Th. (2012). Athel and its relatives: Origin and decline of a noble family of words. In English Studies, 93 (8), p. 950-986.

Vygotsky, L.S. (2012). Thought and language. Cambridge, MA: MIT Press.

Winters, M. (2010). Introduction: On the emergence of diachronic cognitive linguistics. In Historical cognitive linguistics. Winters, M. E., Tissari, H. \& Allan, K. (eds.). Berlin-New York: Walter de Gruyter, p. 3-27.

Zalesova, N. (2009). Formation and perception of the image of a gentleman in language and culture of the USA. Thesis for the Candidate Degree in Philology, Speciality 10.02.04 - Germanic Languages. Moscow: Moscow Lomonosov State University. / Zalesova N. Formirovanie $i$ vosprijatie obraza dzhentel'mena v jazyke $i$ 
kul'ture SShA. Dissertatsiya na soiskaniye stepeni kandidata filologicheskikh nauk. Moskva: Moskovskij gosudarstvennyj universitet. / Залесова Н. Формирование и восприятие образа джентльмена в языке и культуре США. / Диссертация на соискание степени кандидата филологических наук. / Московский государственный университет. 10.02.04 - германские языки. Москва.

Zlatev J., Sonesson G. \& Konderak P. (2016). Introduction: Cognitive semiotics comes of age. In Meaning, mind and communication. Explorations in cognitive semiotics. Frankfurt am Main: Peter Lang, p. 9-31.

\begin{tabular}{|l|l|}
\hline \multicolumn{1}{|c|}{ Contact data } \\
Anastasia Sharapkova \\
CSc. (Philology), \\
Lecturer at English \\
Linguistics Department, \\
Faculty of Philology, \\
Lomonosov Moscow \\
State University, 51, \\
Leninskie gory 1, \\
Moscow, 119991, \\
Russian Federation \\
e-mail:
\end{tabular}

\section{Résumé in English}

Our paper explores the interrelation between socially biased phenomena, affecting the conceptual domain of "knighthood" in XIII-XV centuries and the large scale of semantic shifts influenced by changes in culture and society. We try to reveal how the semantics of words verbalizing "nobility" as the main feature of knighthood is adjusted to the changes in the examined conceptual domain through the texts of Middle and Early-Modern English periods. The emotionally marked concepts are proven to serve an onomasiological "center of attraction" for other words and form a semasiological "center of expansion" for verbalizing other concepts (Blank 1997: 67). The new semiotic bonds are demonstrated to be formed under the influence of contextual 
factors, both individual and social. The integrated approach we apply is deeply rooted in a combination of cognitive linguistics and cultural semiotics. They help elucidate how three types of knighthood (a warrior, a knight proper, and a courtier), which gave rise to three conceptual shifts in the development of knighthood as a social and ethical phenomenon, correlate. These shifts caused a number of changes in the category representing noble and its synonyms worthy, gentle. The dominating adjective noble being a social and cultural sign not only changed its meaning from "renowned, of superior birth" to "having high moral qualities", but also marked the semiotic transition triggered by the development from the older to a new social system and became a cultural meta-metasign. The gradual abstraction and disembodiment of "noble" and other lexical items as linguistic signs lead to a rather complicated conceptual image of "chivalric nobility" since it had been "re-categorized" under the influence of sociocultural changes. Nobility and knighthood as mental entities are gradually becoming more complex bringing forth a highly abstract field of knowledge enriched by the derivative nouns, blended in the same conceptual domain.

Key words: knighthood, semiosis, lexical-semantic shift, metasemiotic shift, sociocultural factors, Middle and Early-Modern English discourse, Middle and EarlyModern English periods.

\section{Résumé in German}

Der Artikel erkundet das Verhältnis zwischen sozial bedingten Phänomenen, die die konzeptuelle Domäne "Rittertum" im XIII-XV. Jahrhundert beeinflussen, und großen semantischen Änderungen, die von Veränderungen in Kultur und Gesellschaft geprägt wurden. Aufgrund der Erforschung von Texten aus den Mittel- und Frühneuenglischen Perioden versuchen wir aufzuzeigen, wie die Semantik der Wörter, die "Adel" als die wichtigste Eigenschaft des Rittertums verbalisieren, sich an die Änderungen in der erforschten Domäne anpasst. Es wird gezeigt, dass emotional markierte Konzepte als onomasiologisches "Zentrum der Anziehung" für andere Wörter fungieren, und ein semasiologisches "Erweiterungszentrum" für die Versprachlichung anderer Konzepte 
bilden (Blank 1997: 67). Weiterhin wird gezeigt, dass die neuen semiotischen Beziehungen unter dem Einfluss von kontextuellen (sowohl individuell als auch sozial bedingten) Faktoren, gebildet wurden. Die gebrauchte Methode wurzelt in einer Kombination von Kognitive Linguistik und Kultursemiotik. Diese Vorgehensweise verdeutlicht, wie die drei Typen von Ritterstand (der Krieger, der Edelman/Ritter, der Höfling), Anlass zu drei konzeptuellen Verschiebungen in der Entwicklung von Rittertum als soziales und ethisches Phänomen, gaben. Diese Verschiebungen verursachten zahlreiche Änderungen in der Kategorie, die das Adjektiv noble und dessen Synonyme worthy und gentle umfasst. Das vorherrschende Adjektiv noble, das ein sozial- und Kulturzeichen ist, hat nicht nur seine Bedeutung von "renowned, of superior birth" zu "having high moral qualities" geändert, sondern es markiert auch den semiotischen Übergang, der durch die Entwiclung von dem älteren zum neueren Sozialsystem verursacht wurde. Die immer zunehmende Abstraktion und "Entkörperlichung" von noble und anderen lexikalischen Einheiten als linguistischen Zeichen führte zu einem ziemlich komplizierten Bild der Vorstellung von "chivalric nobility", weil es unter dem Einfluss von sozial-kulturellen Änderungen rekategorisiert wurde. "Adel" und "Rittertum" als konzeptuelle Einheiten wurden allmählich komplexer und der abstrakte Inhalt wurde durch die abgeleiteten Substantive in derselben Domäne angereichtert.

Stichwörter: Ritterschaft, Semiose, lexikalisch-semantische Verschiebung, sozialkulturelle Faktoren, Mittel- und Frühneuenglischer Diskurs, Mittel- und Frühneuenglischen Perioden. I don't see 'radial category' in German.

\section{Résumé in French}

L'article recherche l'interrelation entre les phénomènes socialement déterminés, qui influencent le domaine conceptuel de "chevalerie" au cours des XIIIe, XIVe et XVe siècles, et les altérations sémantiques à grande échelle conditionnées par les changements culturels et sociaux. En analysant les textes du moyen anglais et de l'anglais moderne naissant, nous tentons de démontrer les mécanismes d'adaptation de 
la sémantique des mots qui verbalisent la "noblesse", principale caractéristique de la chevalerie, aux changements dans le domaine conceptuel examiné. Ainsi, des concepts de marque émotionnelle servent de "centre d'attraction" onomasiologique aux autres mots et constituent le "centre d'expansions" sémasiologique pour la verbalisation des autres concepts (Blank 1997: 67). L'élaboration des nouvelles relations sémiotiques est représentée à se dérouler sous l'influence des facteurs contextuels de détermination individuelle et sociale. L'approche intégrative utilisée se base sur la combinaison de linguistique cognitive et sémiotique culturelle. Cette combinaison aide à clarifier la corrélation de trois types de chevalerie (chevalier militaire, honoraire et courtois) qui donnèrent naissance aux trois changements conceptuels dans l'évolution de chevalerie comme un phénomène social et éthique. Ces changements causèrent un certain nombre d'altérations dans la catégorie représentée par les adjectifs "noble" et ses synonymes "worthy", "gentle". L'adjectif dominant "noble" comme un signe social et culturel non seulement altéra sa définition de "renowned, of superior birth" à "having high moral qualities", mais aussi marqua le changement sémiotique résultant de l'évolution du vieux au nouveau système social. Notre analyse complexe d'évolution des définitions du mot, complété par l'approche cognitive, inclut les caractéristiques lexicosémantiques des adjectifs et noms dérivés de ces adjectifs. Ils exécutent la fonction axiologique dans la nouvelle société féodale formée et jouent un rôle principale dans la lexicalisation des concepts importants culturellement, qui faisaient part de la vision de monde médiévale. L'abstraction graduelle et la "désincarnation" de "noble" et autres unités lexiques, comme signes linguistiques, créent une image conceptuelle de "noblesse chevaleresque" assez complexe, depuis sa "recatégorisation" sous l'influence des changements socioculturels. Noblesse et chevalerie comme des unités conceptuelles deviennent de plus en plus complexes, tandis que leurs éléments abstraits complétés par les dérivés adjectivaux, apparaissent en premier plan.

Mots-clés: la chevalerie, la sémiose, les altérations lexico-sémantiques, le shift métasémiotique, les facteur socio-cultureles, le discours de moyen anglais et d'anglais moderne naissant. 


\section{Résumé in Russian}

Статья исследует соотношение между социально обусловленными явлениями, влияющими на концептуальную область "рыцарство" в XIII-XV веках и масштабными семантическими изменениями, находящимися под влиянием перемен в культуре и обществе. На основе изучения текстов средне и ранненовоанглиского периода мы пытаемся показать как семантика слов, вербализующих "благородство", являющееся основной чертой рыцарства, приспосабливается к изменениям в исследуемом концептуальной области. Так, эмоционально маркированные концепты служат ономасиологическим "центром аттракции" для других слов и формируют семасиологический "центр расширения" для вербализации других концептов (Blank 1997: 67). Показывается, что новые семиотические связи формируются под влиянием как индивидуально, так и социально обусловленных контекстуальных факторов. Применяемый интегративный подход построен на когнитивно лингвистическом и культурно-семиотическом подходах. Они помогают прояснить, как соотносятся три типа рыцарства (воин, благородный рыцарь и рыцарьпридворный), которые дали развитие трем концептуальным сдвигам в развитии рыцарства, как социальном и этическом феномене. Данные сдвиги вызвали целый ряд изменений в категории, репрезентированной прилагательными noble и его синонимами worthy, gentle. Доминирующее прилагательное noble являясь социальным и культурным знаком не только изменило свое значение от "renowned, of superior birth" на "having high moral qualities", но также маркирует семиотический сдвиг, вызванный развитием от более старой к новой социальной системе. Наш комплексный анализ развития значений слова, дополненный когнитивным подходом, включает рассмотрение лексикосемантических характеристик не только прилагательных, но и существительных, от них образованных. Они выполняют аксиологическую функцию в новосформированном феодальном обществе и играют ведущую роль в лексикализации культурно значимых концептов, относящихся к рыцарскому мировидению Средних веков. Прилагательные worthy и gentle также 
сформировали новые семиотические связи и заняли новое место в рамках формирующейся лексической категории. Все большая и большая абстракция и развеществление "noble" и других лексических единиц как лингвистических знаков приводит к достаточно сложной картине представления о рыцарском благородстве, поскольку оно было рекатегоризованно под влиянием социокультурных изменений. Благородство и рыцарство как мыслительные единства постепенно становятся все более сложными, а абстрактное содержание, дополненное отадъективными дериватами, выходит на первый план.

Ключевые слова: рыцарство, семиозис, лексико-семантический сдвиг, социокультурные факторы, среднеанглийский и ранненовоанглийский дискурс, Мэлори.

Article was received by the editorial board 04.07.17.

Reviewed 28.08.17. and 18.09.17.

Similarity Index 5\% 